\title{
Climate Change Impacts: An Assessment for Water Resources Planning and Management in the Pacific Northwest of the U.S
}

\author{
Venkataramana Sridhar and Xin Jin \\ Department of Civil Engineering, Boise State University \\ Boise, Idaho, \\ USA
}

\section{Introduction}

Assessing the hydrological impacts of climate change in the Pacific Northwest (PNW) region of the United States is important. Many global circulation models (GCMs) have a wide range of temperature and precipitation predictions for the PNW region (Bureau of Reclamation, 2011). Numerous studies have reported that decreasing snow pack, increasing temperatures and decreasing streamflow for many basins. For instance, Mote (2003) indicates that annual average temperatures in the Northwest rose faster than the global average during the 20th century. This warming occurred mostly during the winter and spring. The predominance of winter and spring warming, especially in regard to extreme minimum temperatures, was confirmed more recently in a smaller study at two locations: one in Western Montana and the other in British Columbia (Caprio et al., 2009). The warming climate has resulted in a lengthened growing season (Kunkel et al., 2004), decline of snowpack (Mote, 2006), and earlier timing of the spring runoff (Stewart et al., 2005; Hamlet and Lettenmaier, 1999). Water supply in the West is vulnerable to climatic change, mainly because it relies heavily upon the capture of the spring runoff. Precipitation typically accumulates in the mountains as snowpack and is released during the spring melt, which may continue at high elevations into July. Warmer temperatures are likely to lead to more rain and less snow in the winter, causing an increase in the wintertime streamflow and decrease in spring runoff. Warmer weather is also likely to cause snowpack to retreat to higher elevations and experience earlier melt (Hamlet and Lettenmaier, 1999).

\section{Expected future climate}

In our study, we chose the following five models based on the discussion above, which includes all three scenarios, A1B, A2 and B1 for five global circulation models. The models are: MIROC and CCSM3 (wet and warmer winter), HadCM3 (warmer and drier summer) and PCM (cooler and summer). The outputs, primarily precipitation and temperature, from the GCMs are coarser and they needed to be first downscaled to a specific area if we were to get meaningful interpretation of the impacts of climate change at the local scale. The original climate projections are from the World Climate Research Programme's (WCRP's) Coupled 
Model Intercomparison Project phase 3 (CMIP3) multi-model dataset, which was referenced in the Intergovernmental Panel on Climate Change Fourth Assessment Report. We downloaded bias-corrected and spatially downscaled climate projections for the models mentioned above which were derived from CMIP3 data and served at: http://gdodcp.ucllnl.org/downscaled_cmip3_projections/, described by Maurer et al (2007).While there are many methods for downscaling the climate data that can be useful, we preferred this method of bias-corrected and spatially downscaled climate projections as we are using this dataset currently for our Snake River Basin modeling project. The resolution of these datasets is monthly, 1/8th degree gridded products for the study sites. Since we required daily precipitation and temperature data for hydrological modeling, we temporally disaggregated monthly data to a daily time step by delta (change factor) method. There is a six-step procedure we performed to temporally disaggregate the GCM climate model data downloaded from the link above and is shown in Figure 5. This included a random picking of a historical year to compute mean of the daily precipitation and temperature of the gridded observed record for the same month as the future year. By calculating the difference between future monthly mean temperature and historical mean of monthly mean temperature, ' $\Delta \mathrm{t}^{\prime}$ and by calculating the ratio between future monthly mean precipitation and historical mean of monthly mean precipitation, ' $r$ ', we have addition and multiplication factors. Finally, by adding " $\Delta \mathrm{t}$ " to daily temperature of the month of the randomly selected year and multiplying daily precipitation by " $\mathrm{r}$ " for the month of randomly selected year for the given month. We repeated this process for other months of the year for future years and for the remaining grid cells.

For the Boise River basin region between 2010 and 2060, changes in precipitation ranged between $-3.8 \%$ to $36 \%$ (A2), $-9 \%$ to $35 \%$ (A1B) and B1 (-6.7\% to $30.5 \%)$. However, changes in temperature are expected to be between $0.02-3.6{ }^{\circ} \mathrm{C}$ (A2), $0.8-3.9^{\circ} \mathrm{C}$ (A1B) and $0.5-3.1{ }^{\circ} \mathrm{C}$ (B1). In the Spokane River region, changes in precipitation are expected to be between $-3.8 \%$ to14\% (A2), $-6.7 \%$ to $17.9 \%$ (A1B) and $-7.4 \%$ to $14.3 \%$ (B1). Changes in temperature will likely be $0.1-3.2^{\circ} \mathrm{C}(\mathrm{A} 2), 0.8-3.5^{\circ} \mathrm{C}(\mathrm{A} 1 \mathrm{~B})$ and $0.3-2.7^{\circ} \mathrm{C}$ (B1). Overall, the chosen climate models showed a rise in temperature $\left(0.31^{\circ} \mathrm{C}\right.$ to $0.42{ }^{\circ} \mathrm{C} /$ decade for Rathdrum Prairie and $0.34{ }^{\circ} \mathrm{C}$ to $0.46{ }^{\circ} \mathrm{C} /$ decade) and an increase in annual precipitation $(4.7 \%$ to $5.8 \%$ for Rathdrum Prairie and $5.3 \%$ to $8.5 \%$ for Treasure Valley) over a period of next five decades between 2010-2060 (Figure 6 and Figure 7). Precipitation forecast is less certain than temperature trends as there is less agreement among the models. This is generally the case even at the global scale. However, temperature increase is found to be consistent among the models considered in this study. In general, both the regions are expected to see increased annual precipitation (4-8\%) and temperature $\left(0.31-0.45^{\circ} \mathrm{C} /\right.$ decade) when averaged over all the GCMs.

Our objective in this study is to understand and quantify the impacts of climate change in these basins by analyzing the high flows and low flows for the period between 2010 and 2060. These flows have direct implications on how the water resources have to be managed in the basin under future climate conditions. Also, we investigate the importance of biascorrecting (conditioning) the streamflows that are critical for drawing meaningful conclusions for a given basin.

\section{Study area}

\subsection{Boise River basin}

The Boise River is a tributary of the Snake River in southwestern Idaho with a drainage area of 10,619 km2 (Figure 1(a)). The Boise River originates from the three forks of the Sawtooth 
Range that subsequently join together at the Arrowrock Reservoir to form the mainstream flowing west through the Snake River Plain that finally merges with the Snake River at Parma. Topography has west to east gradient, exceeding $3000 \mathrm{~m}$ at the Sawtooth Range and low elevation of $640 \mathrm{~m}$ in the western part near Parma. The basin receives precipitation in the wintertime and the spring snowmelt-induced runoff, which begins in the lower elevations around March, typically continues to contribute a significant amount of streamflow from the high mountains into July. The peak flow period is followed by a relatively dry warm summer. During the fall season, due to reduced transpiration and autumn rainfall as well as the groundwater contribution to baseflow, the streamflow increases slightly. The average annual precipitation in the basin is $661 \mathrm{~mm}$ and average annual mean temperature is $5.9^{\circ} \mathrm{C}$. The land cover in this area is highly diverse, including alpine canyons, forest, rangeland, agriculture land and urban area (Figure 2(a)). The eastern part of the basin (upstream of Lucky Peak Dam) is mainly covered by forests. The lower part of the river basin is covered by grassland, cultivated crops and developed urban areas.

\subsection{Spokane River basin}

The Spokane River is located in the northern Idaho and eastern Washington with a drainage area of 17,200 km² (Figure 1 (b)). It rises from Lake Coeur d'Alene, Idaho and flow west through the Spokane Valley until reaching Spokane, WA. The elevation of the basin increases from west to east and the upper forested catchments receive higher precipitation. The general climate in this area is warm and dry summer (mean temperature $16^{\circ} \mathrm{C}$, total precipitation in winter is $130 \mathrm{~mm}$ ), while cold and moist winter (mean temperature $-3.4^{\circ} \mathrm{C}$, total precipitation during winter is $328 \mathrm{~mm}$ ). The average annual total precipitation is 878 $\mathrm{mm}$ and average annual mean temperature is $6.2^{\circ} \mathrm{C}$. More than $2 / 3$ of the precipitation (319 $\mathrm{mm}$ ) is received in the winter as snow. The average annual evaporation is $420 \mathrm{~mm}$ that is approximately $49 \%$ of the average annual precipitation. The aquifer, known as the Spokane Valley Rathdrum Prairie aquifer (SVRP), is extending from Lake Pend Oreille, Idaho to Spokane, Washington. It is the "sole water aquifer" for its 500,000 population and the aquifer is heavily extracted due to rapid growth in the region and its area is $830 \mathrm{~km}^{2}$ covering the two states. There are a number of lakes surrounding this aquifer that serves as the sources for recharge in addition to precipitation. A series of flooding occurred during the last Glacial Age and made the soil in SVRP primarily unconsolidated coarse-grained sands, gravels, cobbles and boulders with relatively high hydraulic conductivity (Barber et al, 2009). As a result, there is a strong surface water and groundwater interaction between this aquifer and the Spokane River. Reach gains and losses are interlacing from Post Falls, Idaho to Spokane, WA. Land cover in this watershed is dominated by forests and other land cover types include urban or suburban area in the SVRP area and agriculture in the western part of the watershed (Figure 2(b)).

\section{Modeling procedure}

\subsection{Calibration and Validation for the Boise River basin}

The Soil Water Assessment Tool (SWAT) was implemented for our study. SWAT is a continuous simulation model and is widely used with readily available inputs in Geographic Information System (GIS). For data-limited, complex terrain such as ours, this model provides the firsthand information on the hydrological processes relatively easily. Furthermore, we have customized this model for other Idaho watersheds earlier (Stratton et 


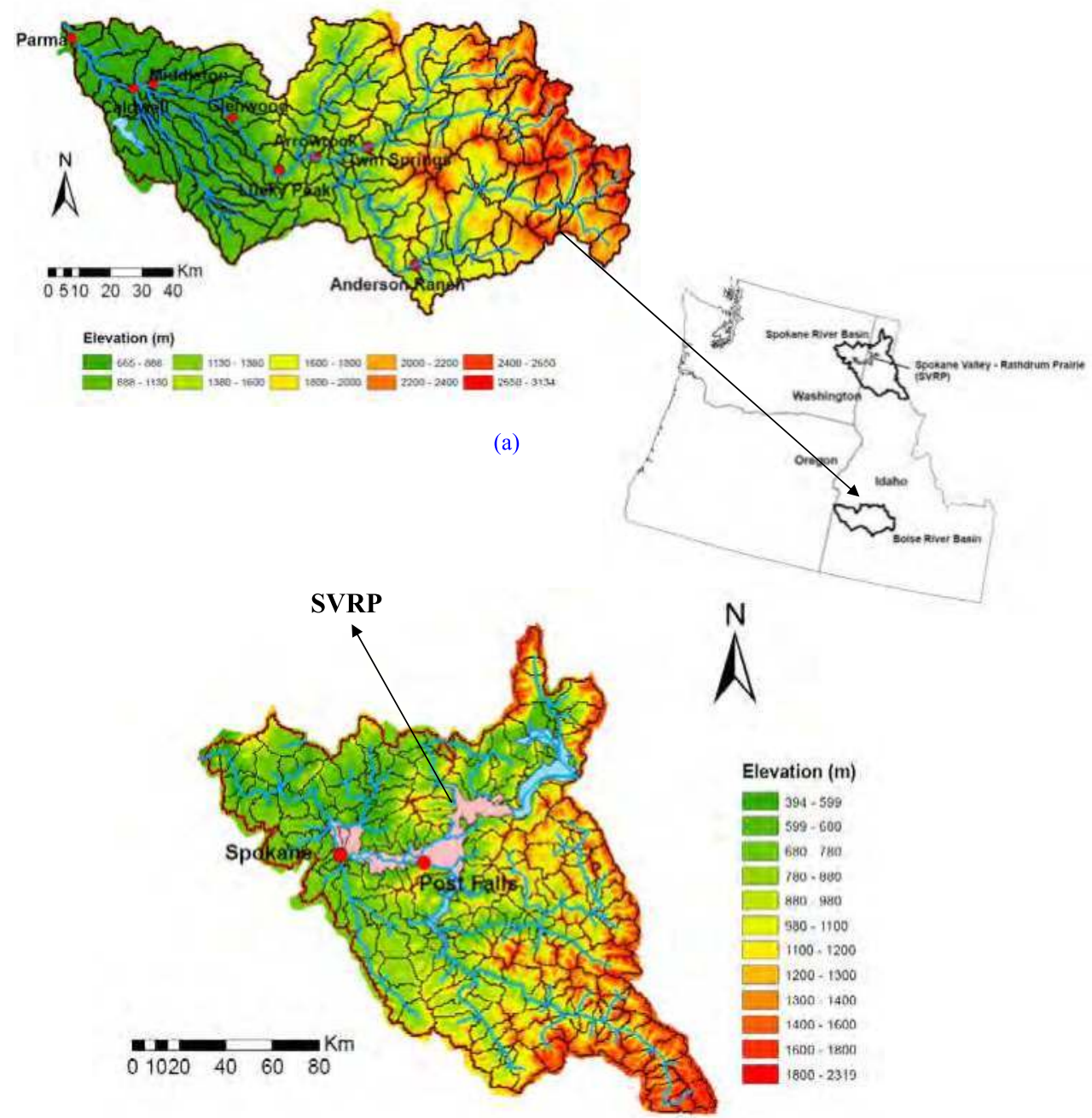

(b)

Fig. 1. Location map showing the Boise River Basin (top) and the Spokane River Basin (bottom).

al., 2009, Sridhar and Nayak, 2010). The basic drivers for this model are USGS-derived Digital Elevation Model, STATSGO soil layer, National Land Cover Data 2001 for vegetation and weather data. We divided the entire basin into 140 sub-basins to represent the spatial heterogeneity of the basin in the model. We also used 74 grids at the $1 / 8$ th degree resolution to drive the hydrology model with GCM-produced precipitation and temperature after 
downscaling them as explained above. The calibration analysis is briefly included here and Jin and Sridhar (2010) provides a detailed description on calibration.

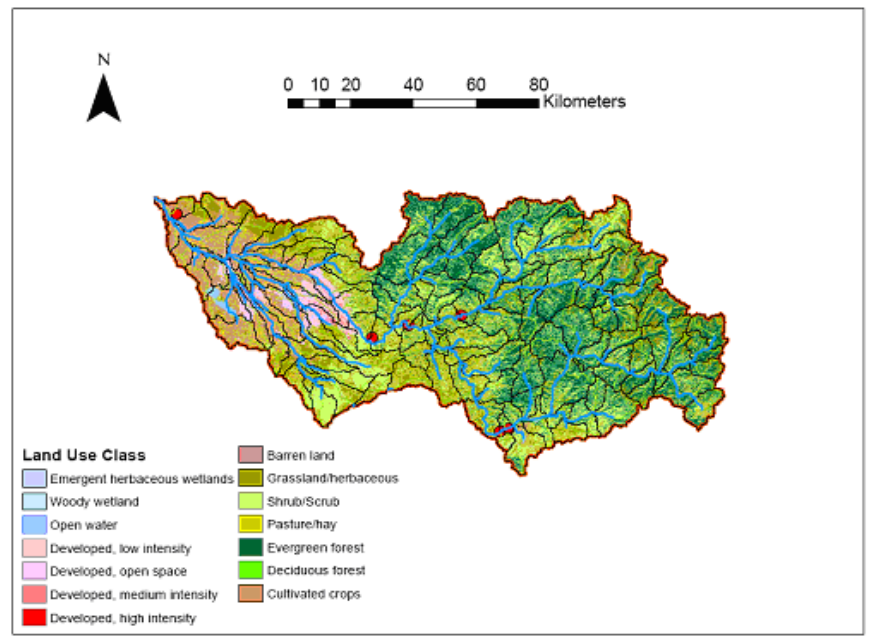

(a)

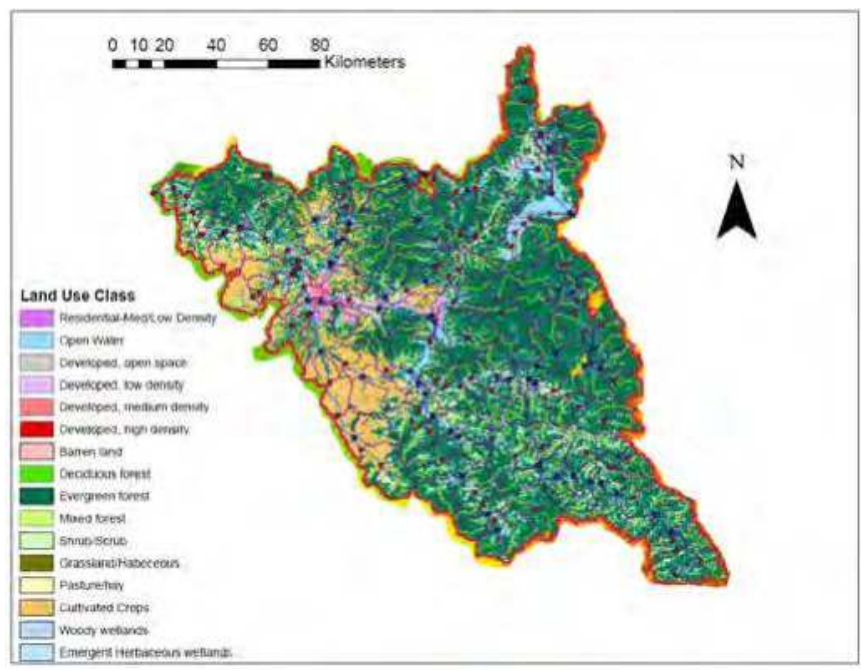

(b)

Fig. 2. Land use map used in the SWAT model from the National Land Cover Data set for (a) the Boise River Basin (b) the Spokane River Basin.

Based on the sensitivity analysis and manual verification, we identified 16 parameters of interest for this basin. We started with all 27 hydrological flow-related parameters and ranked by their order of sensitivity in simulating the basin hydrology. It resulted in about 10 
parameters as the most sensitive ones for this basin. We then manually added additional parameters that were considered to be important for capturing the basin scale hydrological processes. For instance, even if the model sensitivity analysis did not consider melt factor as an important one to be calibrated, we included it manually. Followed by the sensitivity analysis and manual evaluation, we included 16 parameters for our next calibration procedure.

The identified parameters were SCS curve number, deep aquifer percolation fraction, maximum canopy storage, soil depth, threshold water depth in the shallow aquifer, available soil water capacity, saturated hydraulic conductivity, channel effective hydraulic conductivity, soil evaporation compensation factor, plant uptake compensation factor, ground water delay, deep aquifer percolation fraction, surface runoff lag time, snow pack temperature lag factor and snow melt base temperature. These parameters with their optimal values are shown in Table $1(\mathrm{a} \& \mathrm{~b})$. These were considered optimal based on the objective functions, correlation coefficient $\left(\mathrm{R}^{2}\right)$ and Nash-Sutcliff Efficiency (NSE) index. For monthly calibration, as performed in this study, Stratton et al. (2009) suggested that an R2 of greater than or equal to 0.6 is desirable. We additionally considered an NSE factor as another metric for calibration. It can be inferred from our statistical analysis that these metrics rely on the quality of the observed streamflow data as well as spatial and temporal distribution of streamflow gages. Therefore, after identifying the sensitive parameters for both the basins, we generated the optimum parameters based on the autocalibration function, Sequential Uncertainty Fitting Version 2 (SUFI2) calibration algorithm which is explained below. The lower bound and upper bound columns indicate the range a given parameter can move in space while calibrating it. Also, there are options for the parameter estimation within this algorithm, known as IMET options, for replacement, multiplication and addition/subtraction and here we used replacement or multiplication options.

SUFI2 (Sequential Uncertainty Fitting Version2) is a program that is linked with SWAT for calibration. This optimization method calibrates the parameter to achieve best fitness and to the maximum degree to account for the uncertainty between the simulated and measured data. The metric used in this calibration procedure is R-factor and P-factor (Abbaspour, 2008). The calibration process is to adjust the parameter values to make R-factor close to 1 and P-factor close to 0 . This program includes several steps: 1 . Define the objective function; 2. Define the initial range of the parameters; 3 . Perform the sensitivity analysis (optional, but highly recommended); 4. Employ the Latin Hypercube Sampling (LHS) approach of the parameters. The common number of combinations of parameters is $n=500-1000 ; 5$. Run the simulation $\mathrm{n}$ times and save the simulated output variables of interest, corresponding to the measurement; 6 . Calculate the objective function; 7. Calculate the metrics for fitness and uncertainty; 8 . Adjust the range of parameters and repeat " 1 ". By this way, the optimal set of parameters is obtained for the subsequent simulation. SWAT is a HRU-based model that makes the parameters distributed for each HRU. This may be tedious to collect or estimate a large number of parameters for a simulation of even a small watershed. In order to facilitate the calibration of such distributed parameters, SUFI2 has been improved to accommodate the aggregate of parameters. This is implemented by encoding the extended parameters to include the information on what locations to apply a parameter value and hence to aggregate the parameters and this format is adopted in our research.

Historic period was divided into calibration (1958-1963) and validation (1964-2004) windows for this analysis. This splitting of calibration and validation is essential in order to 
Climate Change Impacts: An Assessment for

\begin{tabular}{|c|c|c|c|c|c|c|c|c|c|}
\hline \multirow[b]{2}{*}{$\begin{array}{c}\text { Parameter } \\
\text { name }\end{array}$} & \multirow[b]{2}{*}{ Parameter definition:Parma } & \multirow[b]{2}{*}{$\begin{array}{l}\text { low } \\
\text { bound }\end{array}$} & \multirow[b]{2}{*}{$\begin{array}{c}\text { up } \\
\text { bound }\end{array}$} & \multirow[b]{2}{*}{ imet } & \multicolumn{4}{|c|}{ Calibration Sites } & \multirow[b]{2}{*}{ scale level } \\
\hline & & & & & $\begin{array}{l}\text { Lucky } \\
\text { Peak }\end{array}$ & $\begin{array}{c}\text { Arrowr } \\
\text { ock }\end{array}$ & \begin{tabular}{|c|} 
Twin \\
Springs
\end{tabular} & $\begin{array}{c}\text { Anderson } \\
\text { Ranch }\end{array}$ & \\
\hline Canmx & Maximum canopy storage $(\mathrm{mm})$ & 0.816 & 9.802 & $\mathrm{v}$ & 4.344 & 3.109 & 2.508 & 8.351 & hru \\
\hline $\mathrm{Cn} 2$ & Initial SCS CN II value & -34.77 & 37.44 & $\mathrm{r}$ & -32.5 & -21 & -32.9 & -21.68 & hru \\
\hline Alpha_Bf & baseflow alpha factor (days) & 0 & 1 & $\mathrm{v}$ & & & & & hru \\
\hline Epco & Plant uptake compensation factor & -50 & 50 & $\mathrm{r}$ & & & & & hru \\
\hline Esco & Soil evaporation compensation factor & 0.95 & 1 & $\mathrm{v}$ & & & & & hru \\
\hline Gw_Delay & Groundwater delay (days) & 0 & 192.3 & $\mathrm{v}$ & & & & & hru \\
\hline Gw_Revap & Groundwater revap coefficient & 0.02 & 0.2 & $\mathrm{v}$ & & & & & hru \\
\hline Revapmn & $\begin{array}{l}\text { Threshold water depth in the shallow aquifer } \\
\text { for "revap" (mm) }\end{array}$ & 0.01 & 500 & $\mathrm{v}$ & & & & & hru \\
\hline Gwqmn & $\begin{array}{l}\text { Threshold water depth in the shallow aquifer } \\
\text { for flow }(\mathrm{mm})\end{array}$ & 0 & 673 & $\mathrm{v}$ & 572.2 & 422.3 & 535.5 & 75.5 & hru \\
\hline Rchrg_Dp & Deep aquifer percolation fraction & 0 & 1 & $\mathrm{v}$ & 0.488 & 0.89 & 0.364 & 0.272 & hru \\
\hline Ch_K2 & $\begin{array}{l}\text { channel effective hydraulic conductivity } \\
(\mathrm{mm} / \mathrm{hr})\end{array}$ & 3.8 & 80.8 & $\mathrm{v}$ & 19.8 & 72.3 & 51.01 & 34.2 & subbasin \\
\hline Sol_Awc & Available water capacity $(\mathrm{mm} \mathrm{H} 2 \mathrm{O} / \mathrm{mm}$ soil) & -50 & 50 & $\mathrm{r}$ & 8.9 & 16.9 & 12.38 & 13.9 & hru \\
\hline Sol_K & Saturated hydraulic conductivity $(\mathrm{mm} / \mathrm{hr})$ & 12.5 & 37.5 & $\mathrm{r}$ & & & & & hru \\
\hline Surlag & surface runoff lag time (days) & 0 & 10 & $\mathrm{v}$ & \multicolumn{4}{|c|}{1.446} & basin \\
\hline Timp & Snow pack temperature lag factor & 0.001 & 1 & $\mathrm{v}$ & \multicolumn{4}{|c|}{0.0063} & basin \\
\hline Smtmp & snow melt base temperature $(\mathrm{C})$ & 1.8 & 5.5 & $\mathrm{v}$ & \multicolumn{4}{|c|}{4.1} & basin \\
\hline & note: for imet, $\mathrm{v}$ - replacement, $\mathrm{r}$ - multiplyin & tial va & by va & lue (in & nerco & & & & \\
\hline
\end{tabular}

Table 1 (a). Calibration of the SWAT model using Sequential Uncertainty Fitting algorithm to obtain the optimum parameters representing the basin characteristics for four calibration sites (Lucky Peak, Arrowrock, Anderson Ranch, Twin Springs) in the Boise River Basin.

\begin{tabular}{|c|c|c|c|c|c|c|}
\hline $\begin{array}{l}\text { Parameter } \\
\text { name }\end{array}$ & Parameter definition & $\begin{array}{c}\text { low } \\
\text { bound }\end{array}$ & $\begin{array}{c}\text { up } \\
\text { bound }\end{array}$ & imet & \begin{tabular}{|c|} 
Parma \\
Calibrat \\
ion \\
values
\end{tabular} & scale level \\
\hline Canmx & Maximum canopy storage $(\mathrm{mm})$ & 0.816 & 9.802 & $\mathrm{v}$ & 1.705 & hru \\
\hline $\mathrm{Cn} 2$ & Initial SCS CN II value & -34.77 & 37.44 & $\mathrm{r}$ & 23.6 & hru \\
\hline Alpha_Bf & baseflow alpha factor (days) & 0 & 1 & $\mathrm{v}$ & 0.0601 & hru \\
\hline Epco & Plant uptake compensation factor & -50 & 50 & $\mathrm{r}$ & 9.46 & hru \\
\hline Esco & Soil evaporation compensation factor & 0.95 & 1 & $\mathrm{v}$ & 0.962 & hru \\
\hline Gw_Delay & Groundwater delay (days) & 0 & 192.3 & $\mathrm{v}$ & 173.2 & hru \\
\hline Gw_Revap & Groundwater revap coefficient & 0.02 & 0.2 & $\mathrm{v}$ & 0.191 & hru \\
\hline Revapmn & $\begin{array}{l}\text { Threshold water depth in the shallow aquifer } \\
\text { for "revap" (mm) }\end{array}$ & 0.01 & 500 & $\mathrm{v}$ & 3.66 & hru \\
\hline Gwqmn & $\begin{array}{l}\text { Threshold water depth in the shallow aquifer } \\
\text { for flow ( } \mathrm{mm} \text { ) }\end{array}$ & 0 & 673 & $\mathrm{v}$ & 643.9 & hru \\
\hline Rchrg_Dp & Deep aquifer percolation fraction & 0 & 1 & $\mathrm{v}$ & 0.252 & hru \\
\hline $\mathrm{Ch}$ K2 2 & $\begin{array}{l}\begin{array}{l}\text { channel effective hydraulic conductivity } \\
(\mathrm{mm} / \mathrm{hr})\end{array} \\
\end{array}$ & 3.8 & 80.8 & $\mathrm{v}$ & 13.36 & subbasin \\
\hline Sol_Awc & Available water capacity ( $\mathrm{mm} \mathrm{H} 2 \mathrm{O} / \mathrm{mm}$ soil) & -50 & 50 & $\mathrm{r}$ & -28.88 & hru \\
\hline Sol_K & Saturated hydraulic conductivity (mm/hr) & 12.5 & 37.5 & $\mathrm{r}$ & 36.73 & hru \\
\hline Surlag & surface runoff lag time (days) & 0 & 10 & $\mathrm{v}$ & 1.446 & basin \\
\hline Timp & Snow pack temperature lag factor & 0.001 & 1 & $\mathrm{v}$ & 0.0063 & basin \\
\hline \multirow[t]{2}{*}{ Smtmp } & snow melt base temperature (C) & 1.8 & 5.5 & $\mathrm{v}$ & 4.1 & basin \\
\hline & \multicolumn{6}{|c|}{ note: for imet, $\mathrm{v}$ - replacement, $\mathrm{r}$ - multiplying initial value by value (in percentage) } \\
\hline
\end{tabular}

Table 1 (b). Calibration of the SWAT model using Sequential Uncertainty Fitting algorithm to obtain the optimum parameters representing the basin characteristics for Parma in the Boise River Basin. 
evaluate the performance of the model independent of the calibration effects. The SWAT model was calibrated and verified at five locations (Twin Springs, Anderson Ranch Reservoir, Arrowrock Reservoir, Lucky Peak Reservoir and Parma) in the Boise River basin and two locations (Post Falls and Spokane) in the Spokane River basin, thus covering the large areas of both the basins. The locations were chosen based on the availability of data from U.S Geological Survey (USGS) and the outflow points identified after subdividing the basins into subbasins in the model. Also, it was preferred to distribute the locations from upstream to downstream sections in order to study the impacts and variability of the watershed hydrology due to climate change. Note that some parameters are calibrated at finer scales, which is known as, Hydrological Response Unit (HRU). These HRUs were based on the unique combination of soil, vegetation and slope and are derived from the GIS layers by overlaying them and the total number of HRUs exceeded over 5500. Some other parameters were calibrated at the subbasin level while the remaining parameters were at the basin level.

The selected parameters were subsequently employed for historical hydrological simulations. Statistical results $\left(\mathrm{R}^{2}>0.7\right.$ and Nash-Sutcliff Efficiency $\left.>0.7\right)$ of calibration and historical validation of streamflows are shown in Table 2. Validation of Twin Springs and Anderson Ranch were slightly less when compared with the other sites with NSE of about 0.65 . However, both the sites have an $\mathrm{R}^{2}$ greater than 0.8 for the validation period. It is generally expected the validation period statistics will be similar or slightly inferior to that of the calibration period statistics. Streamflow data used for calibration could be attributed to this decreased NSE in addition to the parameters related to snow-melt induced runoff in these forested upstream locations.

Capturing both low flows and high flows was considered as a prerequisite for our implementation of the model with the calibrated parameters under the climate change scenarios. As changes to the hydrologic conditions are expected to occur rapidly in the future, knowing the historic behavior of flows and hydrology as the baseline reference is critical. Streamflows simulated for historical conditions showed good correlation both in terms of peak flow magnitudes and the timing of snowmelt for the historic climate conditions. Figure 3 shows the correlation between the model-simulated streamflow and observed natural flow for Twin Springs and Lucky Peak. Natural or unmanaged high flows ranged between 113-170 m3/s for the upstream locations and $340-450 \mathrm{~m}^{3} / \mathrm{s}$ for the downstream gaging stations and low flows were between 28-57 m3/s in the Boise River basin. Flows at Twin Springs, Anderson Ranch, Arrow Rock, Lucky Peak, Glenwood, Middleton, Caldwell and Parma were verified. Our simulation also showed that interannual variability in streamflows was relatively high for the Boise River basin for the historic climatic conditions. Other water balance components (evapotranspiration, soil moisture, recharge) were analyzed. Evapotranspiration accounted for $50-60 \%$ of total precipitation annually. Soil moisture and recharge accounted for about $10-15 \%$ of annual precipitation.

\subsection{Calibration for the Spokane River basin}

Similar to earlier implementation, the SWAT model was configured to run for the whole of Spokane River basin in order to establish the hydrologic connectivity and the watershed characterization including the aquifer. To understand the flow pattern in the upstream portion of the Spokane River basin which lies in Idaho, it is essential to consider the entire 


\begin{tabular}{|c|c|c|c|c|c|}
\hline Subbasin & & $r^{2}$ & NSE & P-factor & R-factor \\
\hline \multirow{2}{*}{ Parma } & calibrated (1959 - 1963) & 0.80 & 0.73 & 0.50 & 0.40 \\
\cline { 2 - 6 } & validated (1964 - 2004) & 0.82 & 0.79 & & \\
\hline \multirow{2}{*}{ Lucky Peak } & calibrated (1959 - 1963) & 0.79 & 0.78 & 0.32 & 0.43 \\
\cline { 2 - 6 } & validated (1964 - 2004) & 0.78 & 0.73 & & \\
\hline \multirow{2}{*}{ Arrow Rock } & calibrated (1959 - 1963) & 0.75 & 0.75 & 0.32 & 0.45 \\
\cline { 2 - 6 } & validated (1964 - 2004) & 0.77 & 0.70 & & \\
\hline \multirow{2}{*}{ Twin Spring } & calibrated (1959 - 1963) & 0.87 & 0.85 & 0.4 & 0.5 \\
\cline { 2 - 6 } & validated (1964 - 2004) & 0.81 & 0.65 & & \\
\hline \multirow{2}{*}{ Anderson Ranch } & calibrated (1959 - 1963) & 0.87 & 0.70 & 0.4 & 0.55 \\
\cline { 2 - 6 } & validated (1964 - 2004) & 0.83 & 0.64 & & \\
\hline
\end{tabular}

Table 2. Calibration and Validation statistics for various gaging locations in the Boise River Basin.
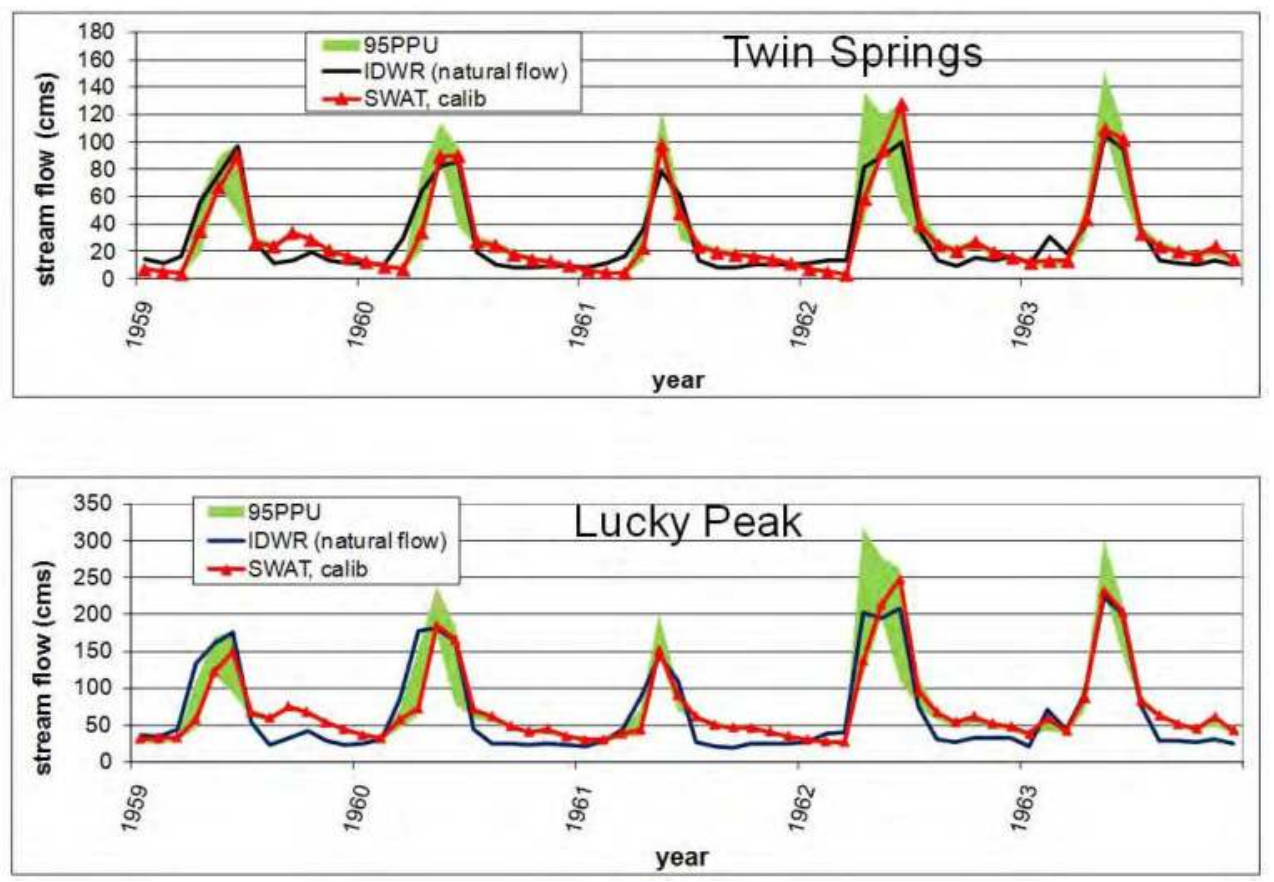

(a) 

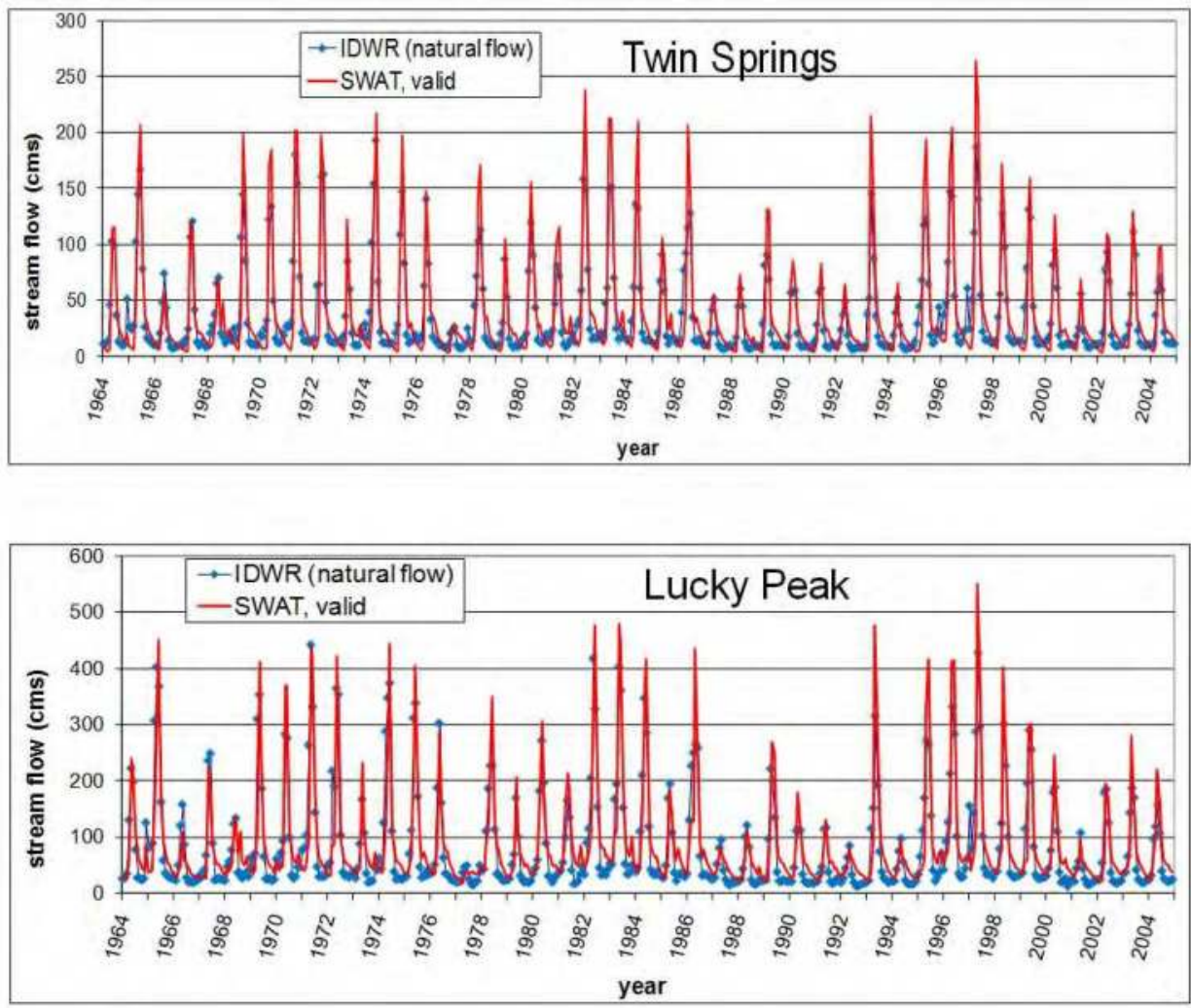

(b)

Fig. 3. Streamflows for Twin Springs and Lucky Peak simulated by the SWAT model during (a) calibration (1959-1963) and (b) validation period (1964-2004).

watershed beyond Idaho borders. Therefore, our delineation of the basin includes both the regions in Idaho and Washington. There are 226 sub-basins and over 5700 HRUs derived from a combination of DEMs, slope and soil layers and 144 weather points within this basin to drive the model with the GCM data.

We identified 15 sensitive parameters for this basin and they included surface flow, groundwater, soil and snow parameters similar to that of the Boise River region. Initial calibration was performed by dividing the region above Post Falls and the region below Post Falls. A combination approach of autocalibration using SUFI algorithm followed by manual calibration for the Post Falls and Spokane streamflow stations showed good correlation for the historic period. Optimum values of the parameters are shown in Table 3. The parameters that we calibrated were baseflow factor, maximum canopy storage, SCS curve number, deep aquifer percolation fraction, soil evaporation compensation factor, plant uptake compensation factor, ground water delay, deep aquifer percolation fraction, threshold water depth in the shallow aquifer, available soil water capacity, saturated hydraulic conductivity, channel effective hydraulic conductivity, surface runoff lag time, snow pack temperature lag factor and snow melt base temperature. 


\begin{tabular}{|c|c|c|c|c|c|c|c|}
\hline \multirow[b]{2}{*}{$\begin{array}{c}\text { Parameter } \\
\text { name }\end{array}$} & \multirow[b]{2}{*}{ Parameter definition:Parma } & \multirow[b]{2}{*}{$\begin{array}{c}\text { low } \\
\text { bound }\end{array}$} & \multirow[b]{2}{*}{ up bound } & \multirow[b]{2}{*}{ imet } & \multicolumn{2}{|c|}{ Calibration Sites } & \multirow[b]{2}{*}{ scale level } \\
\hline & & & & & Post Falls & $\begin{array}{l}\text { Spokane to } \\
\text { Post Falls }\end{array}$ & \\
\hline Alpha_Bf & baseflow alpha factor (days) & 0.05 & 0.15 & $\mathrm{v}$ & 0.077 & 0.079 & hru \\
\hline Canmx & Maximum canopy storage $(\mathrm{mm})$ & 1.28 & 3.84 & $\mathrm{v}$ & 2.7 & 1.8 & hru \\
\hline Ch_K2 & channel effective hydraulic conductivity $(\mathrm{mm} / \mathrm{hr})$ & 10 & 30 & $\mathrm{v}$ & 31.5 & 19.9 & subbasin \\
\hline $\mathrm{Cn} 2$ & Initial SCS CN II value & 6.38 & 19.14 & $\mathrm{r}$ & 7.78 & 12.9 & hru \\
\hline Epco & Plant uptake compensation factor & -50 & 50 & $\mathrm{r}$ & 16.1 & -37.4 & hru \\
\hline Esco & Soil evaporation compensation factor & 0.33 & 1 & $\mathrm{v}$ & 0.55 & 0.9 & hru \\
\hline Gw_Delay & Groundwater delay (days) & 101 & 303 & $\mathrm{v}$ & 188.4 & 146.7 & hru \\
\hline Gw_Revap & Groundwater revap coefficient & 0.047 & 0.141 & $\mathrm{v}$ & 0.093 & 0.133 & hru \\
\hline Gwqmn & Threshold water depth in the shallow aquifer for flow (mm) & 219 & 656 & $\mathrm{v}$ & 333.8 & 299.2 & hru \\
\hline Revapmn & Threshold water depth in the shallow aquifer for "revap" (mm) & 0.01 & 500 & $\mathrm{v}$ & 299.1 & 146.9 & hru \\
\hline Sol_Awc & Available water capacity $(\mathrm{mm} \mathrm{H} 20 / \mathrm{mm}$ soil) & 12.5 & 37.5 & $\mathrm{r}$ & 18.6 & 33.3 & hru \\
\hline Sol_K & Saturated hydraulic conductivity $(\mathrm{mm} / \mathrm{hr})$ & 4.27 & 12.8 & $\mathrm{r}$ & 5.7 & 13.2 & hru \\
\hline Surlag & surface runoff lag time (days) & 2.27 & 6.81 & $\mathrm{v}$ & \multicolumn{2}{|c|}{6.3} & basin \\
\hline Timp & Snow pack temperature lag factor & 0.01 & 1 & $\mathrm{v}$ & \multicolumn{2}{|c|}{0.0035} & basin \\
\hline \multirow[t]{2}{*}{ Smtmp } & snow melt base temperature $(\mathrm{C})$ & 1.61 & 4.83 & $\mathrm{v}$ & \multicolumn{2}{|c|}{3.39} & basin \\
\hline & \multicolumn{3}{|c|}{ note: for imet, $\mathrm{v}$ - replacement, $\mathrm{r}$ - multiplying initial value by value (in percentage) } & & & & \\
\hline
\end{tabular}

Table 3. Calibration of the SWAT model using Sequential Uncertainty Fitting algorithm to obtain the optimum parameters representing the basin characteristics in the Spokane River Basin.

The calibrated SWAT model was verified at two locations (Post Falls and Spokane) in the Spokane River basin, thus covering the large areas of the Spokane River basin (Figure 2). Both seasonality and peakflows were captured by the model under historic climate conditions. Statistical results with R2 $>0.65$ and Nash-Sutcliff Efficiency $>0.55$ for the calibration and historical validation with $\mathrm{R} 2>0.66$ for the model performance in predicting streamflows are shown in Table 4. However, for the second validation period, 1981-99, both R2 (0.66) and NSE (0.41) have shown a slightly inferior performance of the model. Normally, the validation period statistics is somewhat lower when compared against the calibration period and we found it to be the case in this study also. However, the correlation coefficient of 0.6 was considered reliable in order for us to use this as a predictive tool in our hydrological impact analysis.

\begin{tabular}{|c|c|c|c|c|c|c|}
\hline Subbasin & Gage station & & $r^{2}$ & NSE & P-factor & R-factor \\
\hline \multirow{3}{*}{ Post Falls } & \multirow{3}{*}{ Post Falls, ID, 12419000 } & calibrated (1978 - 1980) & 0.76 & 0.58 & 0.39 & 0.45 \\
\cline { 3 - 8 } & & validated (1953 -1977) & 0.72 & 0.65 & & \\
\cline { 3 - 8 } & & validated (1981 -1999) & 0.66 & 0.48 & & \\
\hline \multirow{3}{*}{ Spokane } & \multirow{3}{*}{ Spokane, WA, 12422500 } & calibrated (1978 - 1980) & 0.75 & 0.55 & 0.33 & 0.46 \\
\cline { 3 - 8 } & & validated (1953 -1977) & 0.71 & 0.62 & & \\
\cline { 3 - 8 } & & validated (1981 -1999) & 0.66 & 0.41 & & \\
\hline
\end{tabular}

Table 4. Calibration and Validation statistics for various gaging locations in the the Spokane River Basin.

For the Spokane River basin, high flows ranged between 560-850 m3/s. Historic climate analysis showed that interannual variability in streamflow was relatively high for the Bois River basin. However, this was slightly less in the Spokane River basin which can be attributed to precipitation variability in the historic climatic conditions. There was an earlier snowmelt for both the regions as a result of increasing temperature trends, especially at lower elevations. Streamflows simulated by the model was verified against the observations. Figure 4 shows the time series of streamflows captured by the model for Post Falls and Spokane gaging stations. 

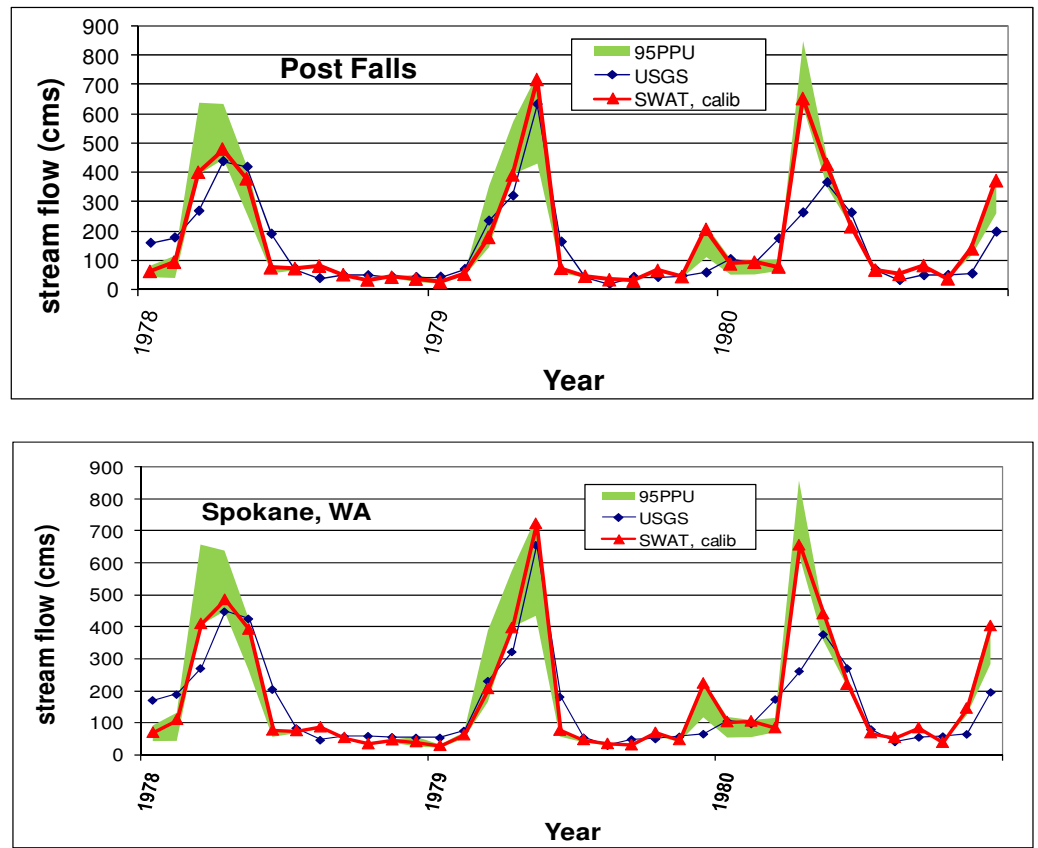

(a)
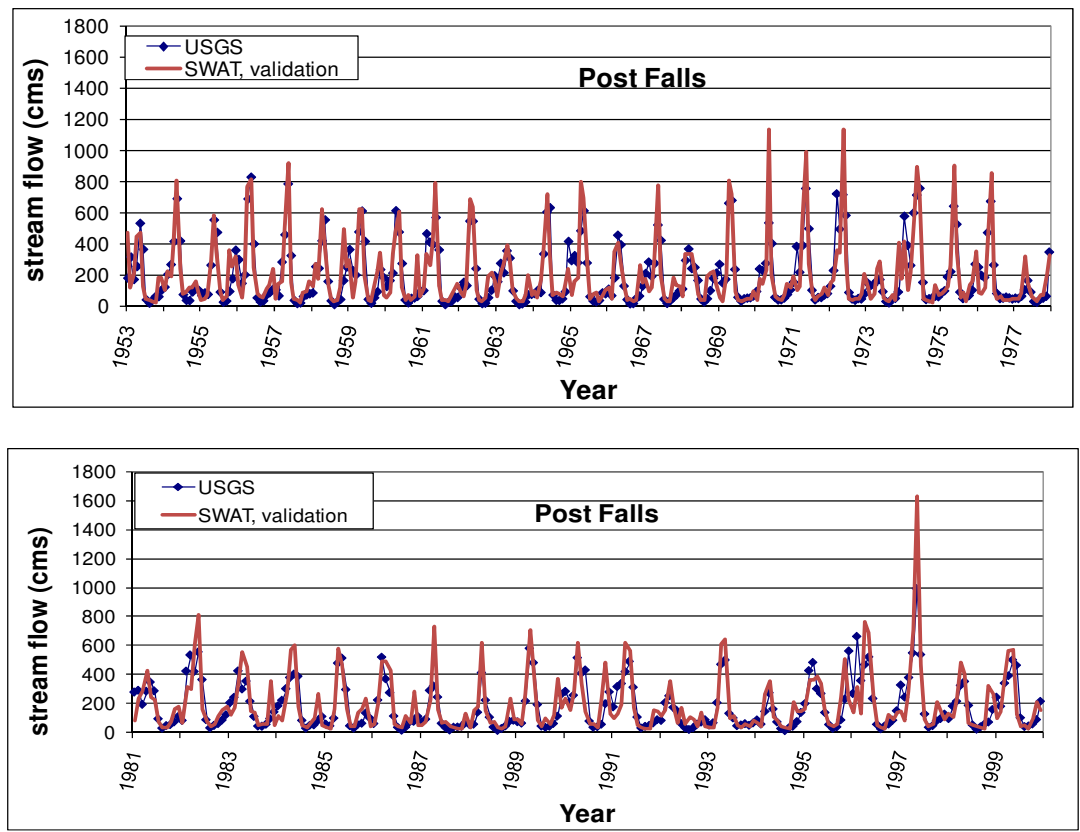
Climate Change Impacts: An Assessment for
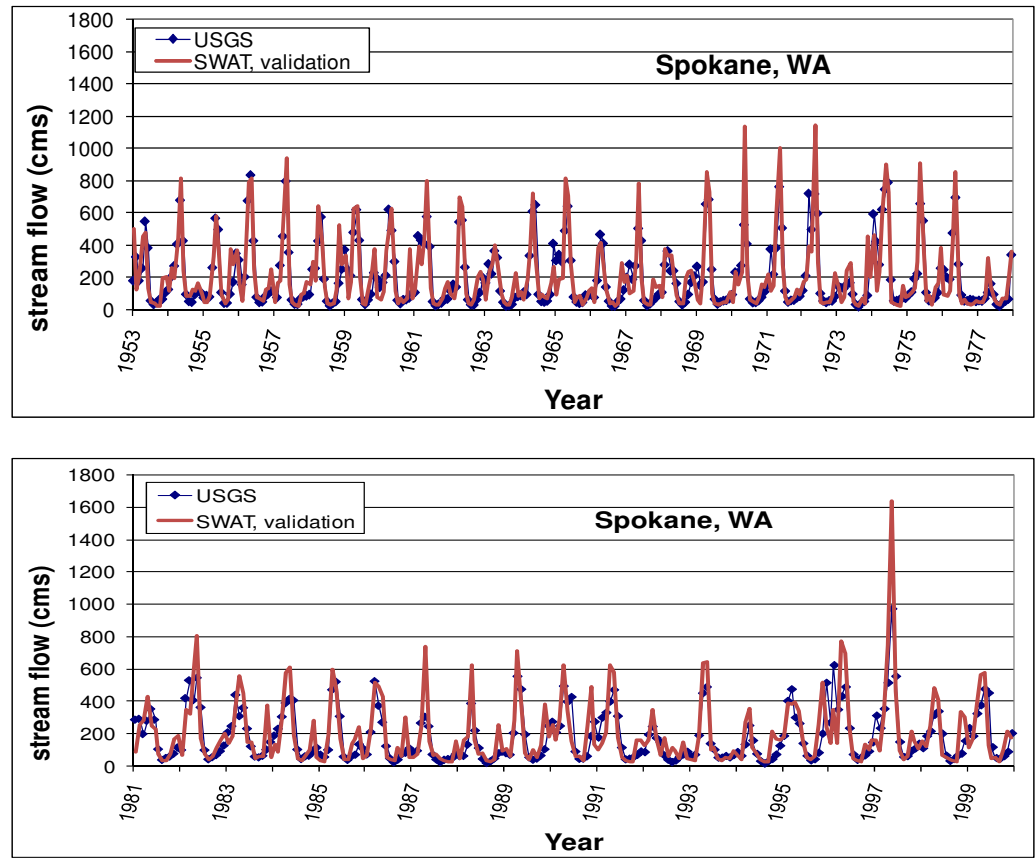

(b)

Fig. 4. Streamflows for Post Falls and Spokane simulated by the SWAT model during (a) calibration (1978-1980) and (b) validation period (1953-1977; 1981-2000).

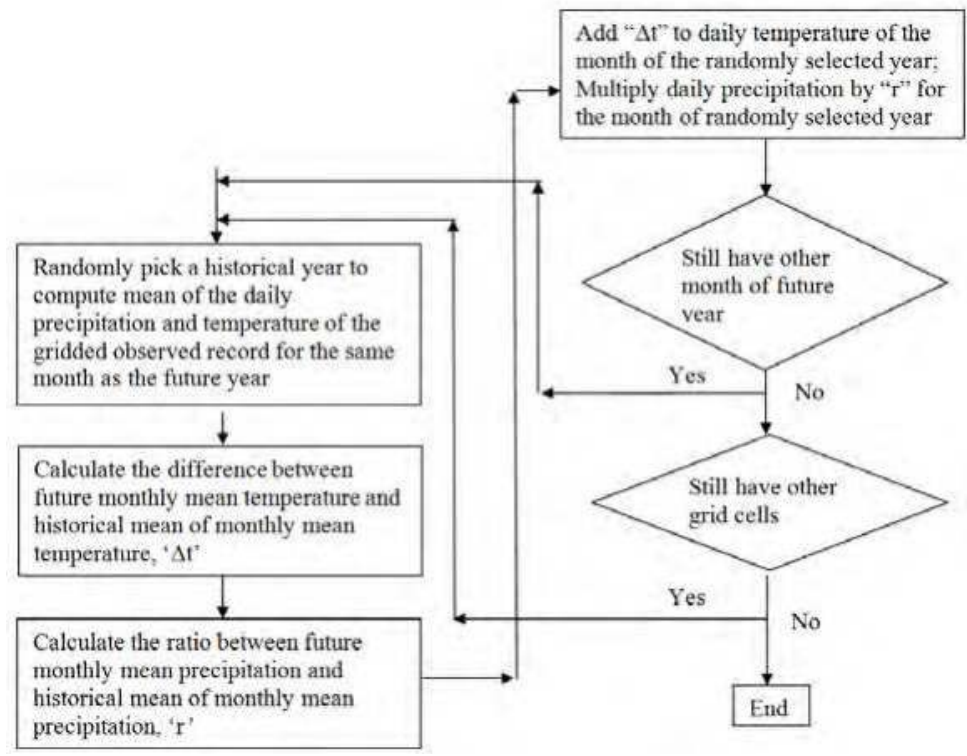

Fig. 5. Flowchart of downscaling method for precipitation and temperature. 

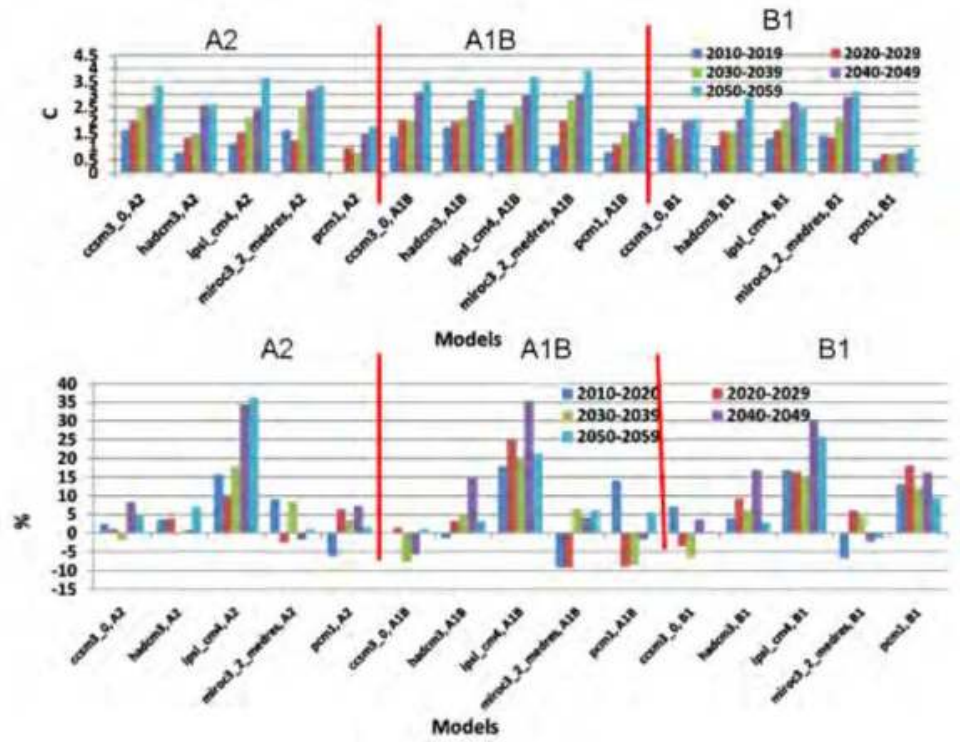

Fig. 6. Temperature (top) and Precipitation (bottom) trends under climate change conditions for the Boise River basin between 2010 and 2060. The models used are CCSM3, HADCM3, IPSL CM4, MIROC 3.2 and PCM.

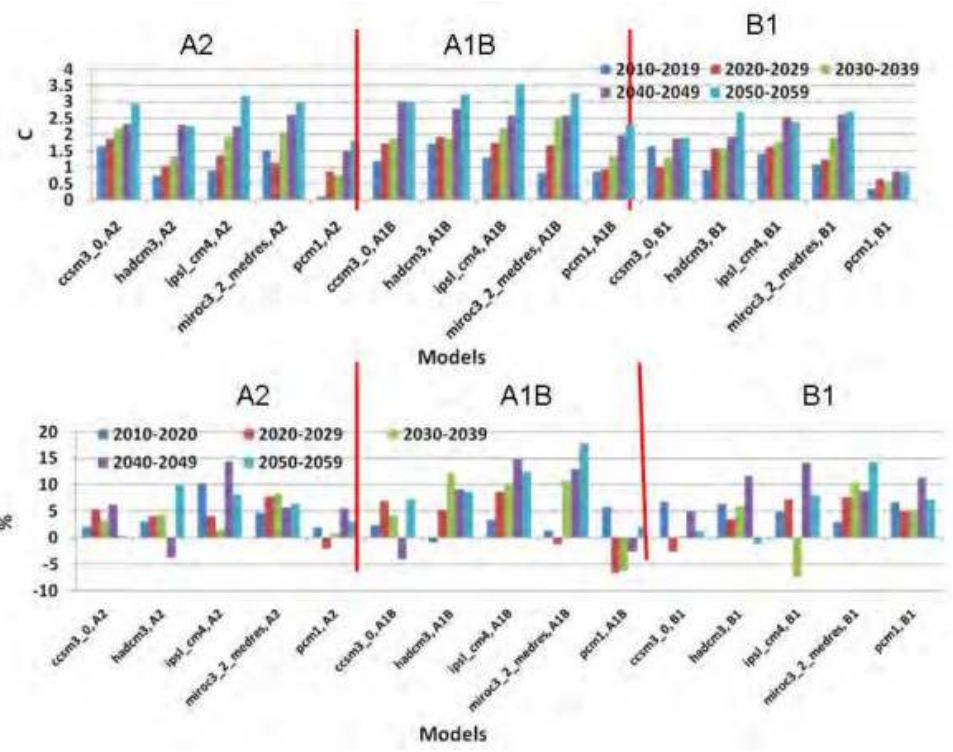

Fig. 7. Temperature (top) and Precipitation trends under climate change conditions for the Spokane River basin between 2010 and 2060. The models used are CCSM3, HADCM3, IPSL CM4, MIROC 3.2 and PCM. 


\section{Results and discussion}

\subsection{Bias correction of streamflow}

While the calibration exercise resulted in reasonable correlation $(\mathrm{r}=0.8)$ between the simulated and observed streamflow, we recognized a positive bias from the model estimates were to be corrected. This is especially the case when the peak flows and low flows are overestimated. These are the times when future climate model-based predictions are sensitive to earlier melt and altered low flow regions. By correcting the bias, applications of future streamflow projections can be made useful for water resources planning and management purposes.

In order to perform the bias correction, we first averaged the monthly streamflows for the historic periods for each month. For instance, historical January flows were averaged for each gaging locations and subtracted from modeled flows of future projections for the same month. This is repeated for each month in a year and for each location. This bias correction exercise reduced model-simulated peak flows and low flows that were comparable to historic trends.

\subsection{High flows}

The seasonal flows can be divided into high flows and low flows. The high flows are defined in our study as the flows that occur between March and June. We computed high flows for various locations within the basin. This high flow analysis is critical especially in the context of climate change as we expect increased flows in the region due to increased precipitation according to the choice of the models in this study.

As a result of the increased precipitation and temperature, generally both the regions are expected to have increased streamflows during the peak flow season (Figure 8) and decreased flows in the summer. In order to make sure that flows are realistic, we biascorrected the predicted flows by comparing with the long-term flow data. With all the climate scenarios that have been analyzed in the study, a wide range of predictions is probable for the entire 50 year period between 2010 and 2060. The choice of the model in understanding the flow pattern becomes critical. This was observed for all the emission scenarios, A1B, A2 and B1 where we have projected mostly increased precipitation possibilities and the range of peak flows (March through June) is expected to increase by $116.6 \mathrm{cms}$ (A2), $93.0 \mathrm{cms}$ (A1B) and $110.9 \mathrm{cms}$ (B1). This is based on the average of the eight sites in the Boise River basin where flows are predicted by the model. However, there are uncertainties in these predictions as evidenced from decreases in peak flows predicted in some scenarios. An eight site average of decrease in peak flows for the Boise River basin revealed the flows as $34.6 \mathrm{cms}$ (A2), $47.9 \mathrm{cms}$ (A1B) and $38.7 \mathrm{cms}$ (B1). These are due to some scenarios where precipitation is predicted to be decreasing. In general, the peak flow averages expected to increase by $17.6 \mathrm{cms}$ (A2), $11.0 \mathrm{cms}$ (A1B) and $22.4 \mathrm{cms}$ (B1). Thus, the high flows in the future will probably be higher than historic high flows. Table 5(a) shows the flows based on the averages from eight sites.

As in Figure 9, in the Rathdrum Prairie basin the peak flow increases are expected to be about $71.5 \mathrm{cms}$ (A2), $17.3 \mathrm{cms}$ (A1B) and $53.8 \mathrm{cms}$ (B1) based on the two site average flows predicted by the model. However, the decreases in peakflows are also greater than that of the decreases in the Boise River Basin. For instance, a decrease in peak flows by $206.8 \mathrm{cms}$ (A2), $215.0 \mathrm{cms}$ (A1B) and $170.7 \mathrm{cms}$ (B1) are also simulated by some scenarios that predict a decrease in precipitation. Precipitation uncertainty causing flow variations appears to be 
magnified in the higher latitudes such as the Rathdrum Prairie basin. However, nearly all scenarios agree that there will be a slight advancement in the timing of snow melt in the Treasure Valley and the Rathdrum Prairie basins. The peak flow averages are expected to decrease by about $74.4 \mathrm{cms}$ (A2), $93.9 \mathrm{cms}$ (A1B) and $65.2 \mathrm{cms}$ (B1). Table 5(b) shows the flows based on the averages from eight sites.

\begin{tabular}{|c|c|c|c|}
\hline & A2 & A1B & B1 \\
\hline $\begin{array}{c}\text { Peak flow maximum } \\
\text { decrease (cms) }\end{array}$ & 34.6 & 47.9 & 38.7 \\
\hline $\begin{array}{c}\text { Peak flow maximum } \\
\text { increase (cms) }\end{array}$ & 116.6 & 93.0 & 110.9 \\
\hline $\begin{array}{c}\text { Peak flow mean increase } \\
(\mathrm{cms})\end{array}$ & 17.6 & 11.0 & 22.4 \\
\hline
\end{tabular}

(a)

\begin{tabular}{|c|c|c|c|}
\hline & A2 & A1B & B1 \\
\hline $\begin{array}{c}\text { Peak flow maximum } \\
\text { decrease (cms) }\end{array}$ & 206.8 & 215.0 & 170.7 \\
\hline $\begin{array}{c}\text { Peak flow maximum } \\
\text { increase (cms) }\end{array}$ & 71.5 & 17.3 & 53.8 \\
\hline $\begin{array}{c}\text { Peak flow mean decrease } \\
(\mathrm{cms})\end{array}$ & 74.4 & 93.9 & 65.2 \\
\hline
\end{tabular}

(b)

Table 5. (a) The Boise River Basin future peak flow change range (8-site average) between 2010-2060 for each scenario (A2, A1B and B1) ; (b) The Rathdrum Prairie Basin future peak flow change range (2-site average) between 2010-2060 for each scenario (A2, A1B and B1).

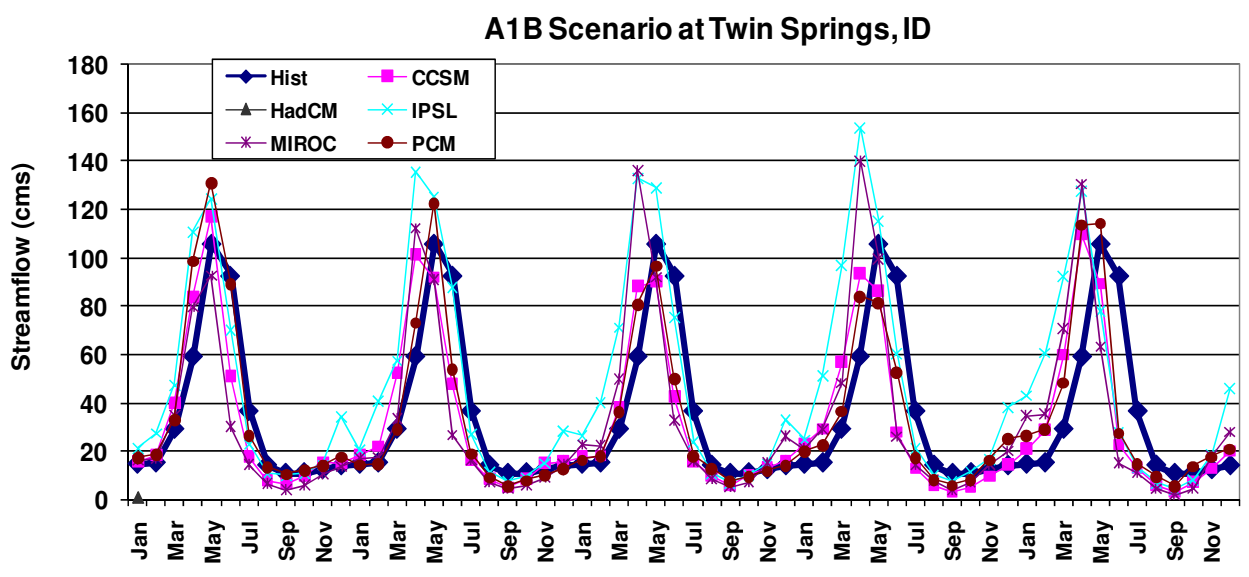

(A1B) 


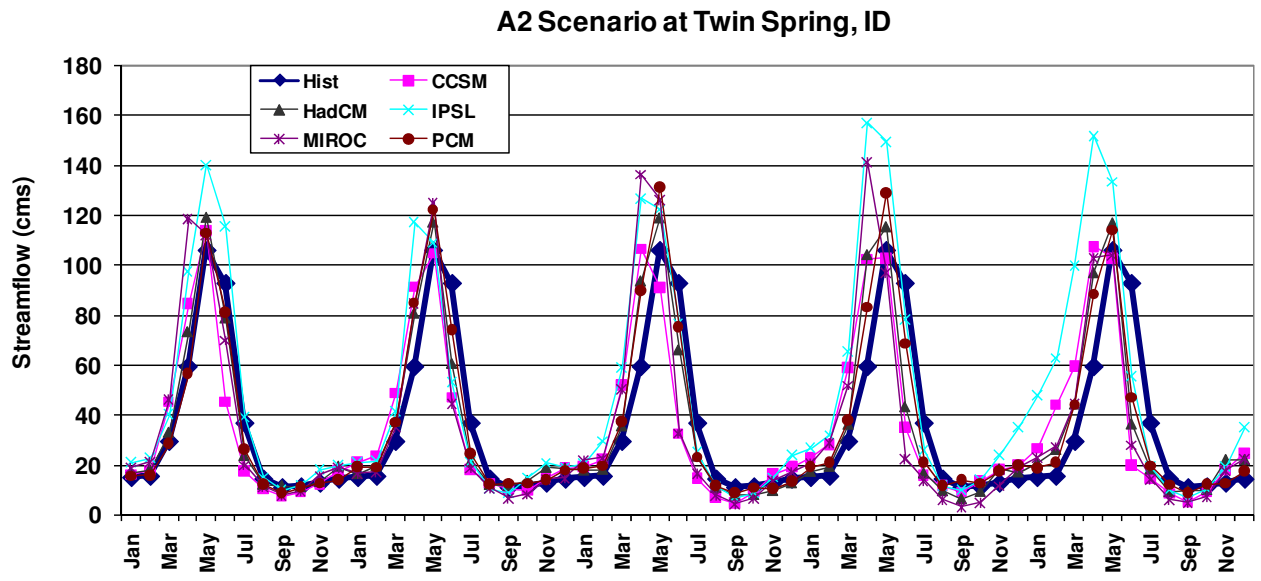

(A2)

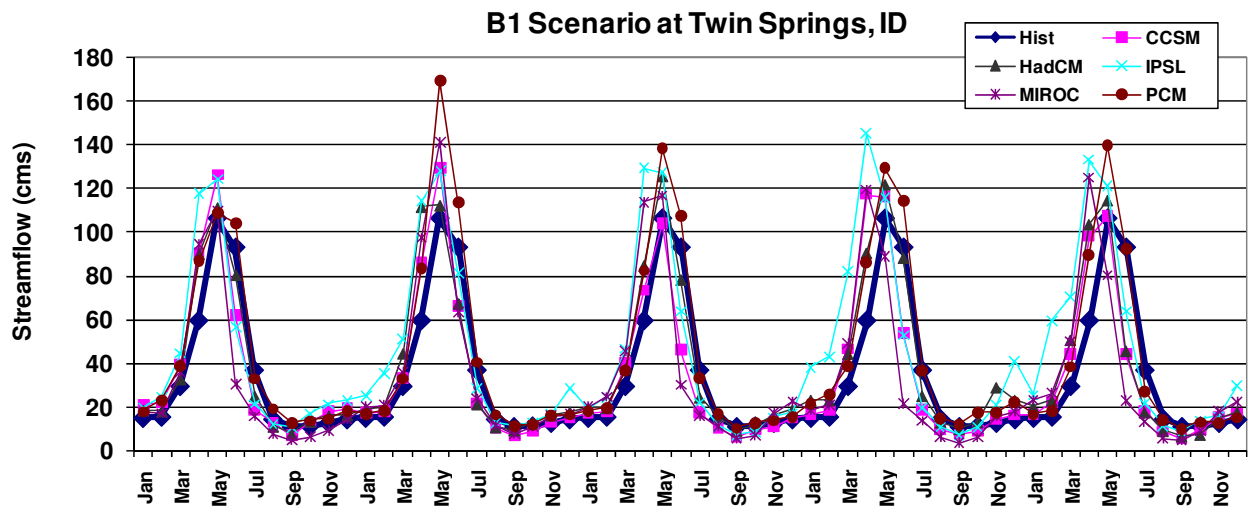

(B1)

Fig. 8. Seasonal streamflows for each decade between 2010 and 2060 at Twin Springs in the Upper Boise River basin for each scenario for A1B (top), A2 (middle) and B1 (bottom). Higher peak flows are expected to occur in May and low flows are about the same or slightly above when compared against the historic flows.

\subsection{Low flows}

Streamflows in the low flow period (July through Oct) are decreasing in the Boise River basin. More specifically, the average maximum increase in the summertime flows are 5.5 $\mathrm{cms}$ (A2), $2.2 \mathrm{cms}$ (A1B) and $9.5 \mathrm{cms}$ (B1) scenarios. Minimum low flows predicted by the model have projected decreasing flows by $17.6 \mathrm{cms}$ (A2), $18.7 \mathrm{cms}$ (A1B) and $17.2 \mathrm{cms}$ (B1). In general, the low flow averages declined in the future by $8.0 \mathrm{cms}$ (A2), $10.7 \mathrm{cms}$ (A1B) and $6.2 \mathrm{cms}$ (B1). Notably, the low flows are expected to be lower than historic low flows 


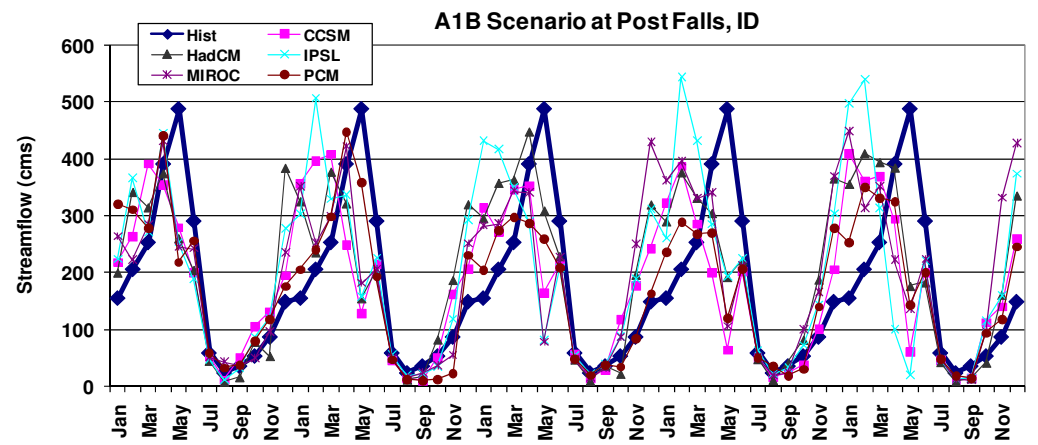

(A1B)

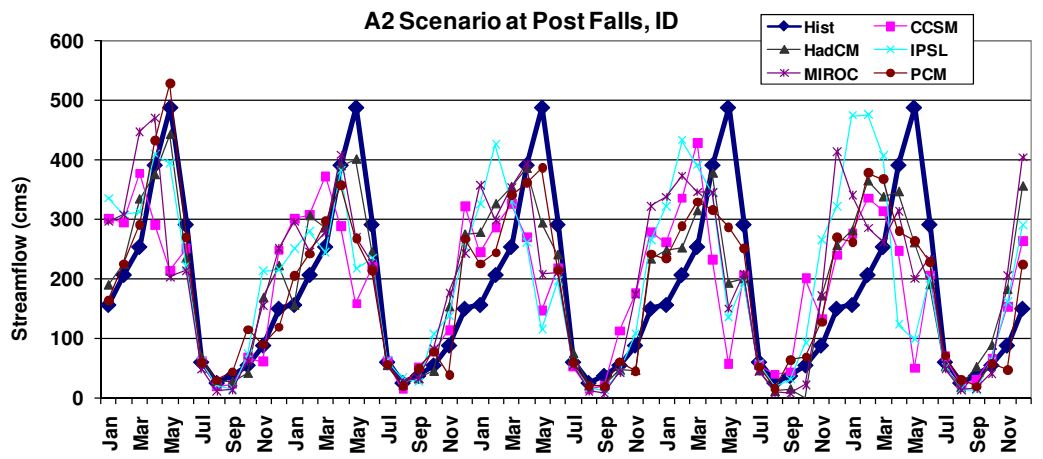

(A2)

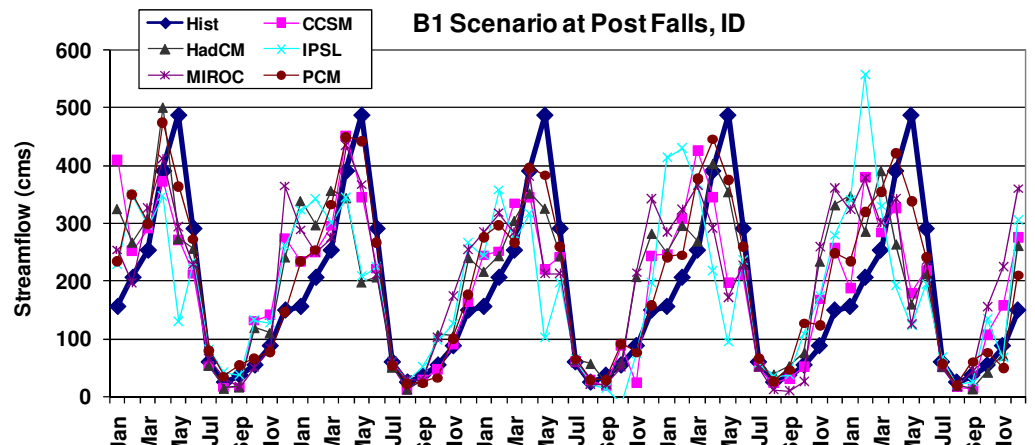

(B1)

Fig. 9. Seasonal streamflows for each decade between 2010698 and 2060 at Post Falls in the Spokane River Basin for each scenario for A1B (top), A2 (middle) and B1 (bottom). Higher peak flows are expected to occur in May and low flows are about the same or slightly above when compared against the historic flows. Low flows are about the same or slightly below when compared against the historic flows. 
(Figure 10). The summertime minimum low flows in the Rathdrum Prairie appear to have decreased when compared against the historic conditions (Figure 11). For instance, a decrease in flow by $29.4 \mathrm{cms}$ (A2), $25.6 \mathrm{cms}$ (A1B) and $29.7 \mathrm{cms}$ (B1) is predicted. The maximum low flows are increasing by $52.3 \mathrm{cms}$ (A2), $27.0 \mathrm{cms}$ (A1B) and $46.3 \mathrm{cms}$ (B1). A minimal increase in the average low flows, rather than a decrease as in the Treasure Valley region, by about $5.4 \mathrm{cms}$ (B1) is simulated by these models. The results are shown in Table 6 $(\mathrm{a} \& \mathrm{~b})$. While most of the increase could be attributed to climate change, as can be noticed from our historic model validation approximately some $20 \%$ of the flows were unexplained by mode $\left(\mathrm{r}^{2}=0.8\right)$ and therefore uncertainty in the hydrological model predictions should be included when planning the water availability forecasts.
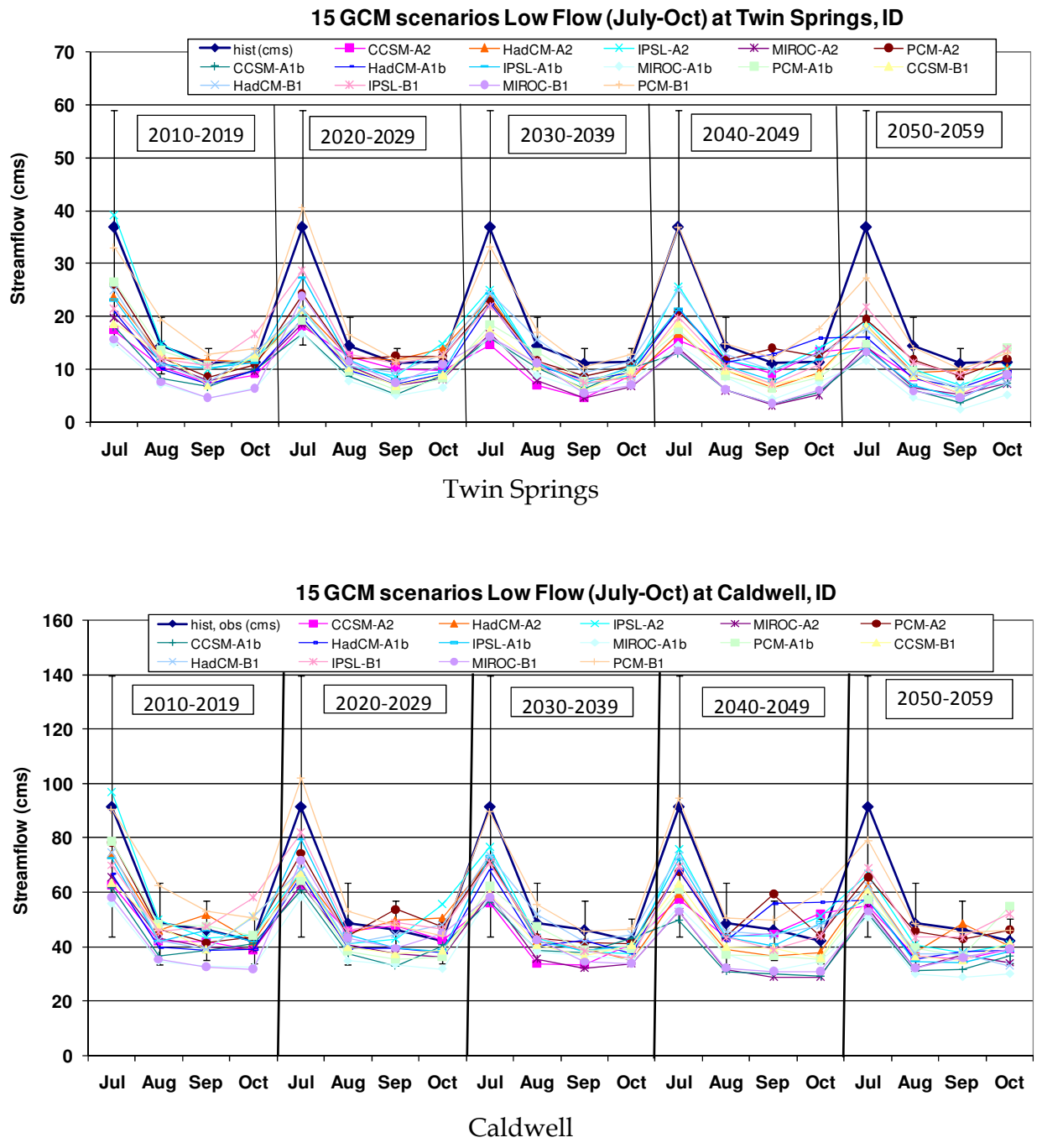


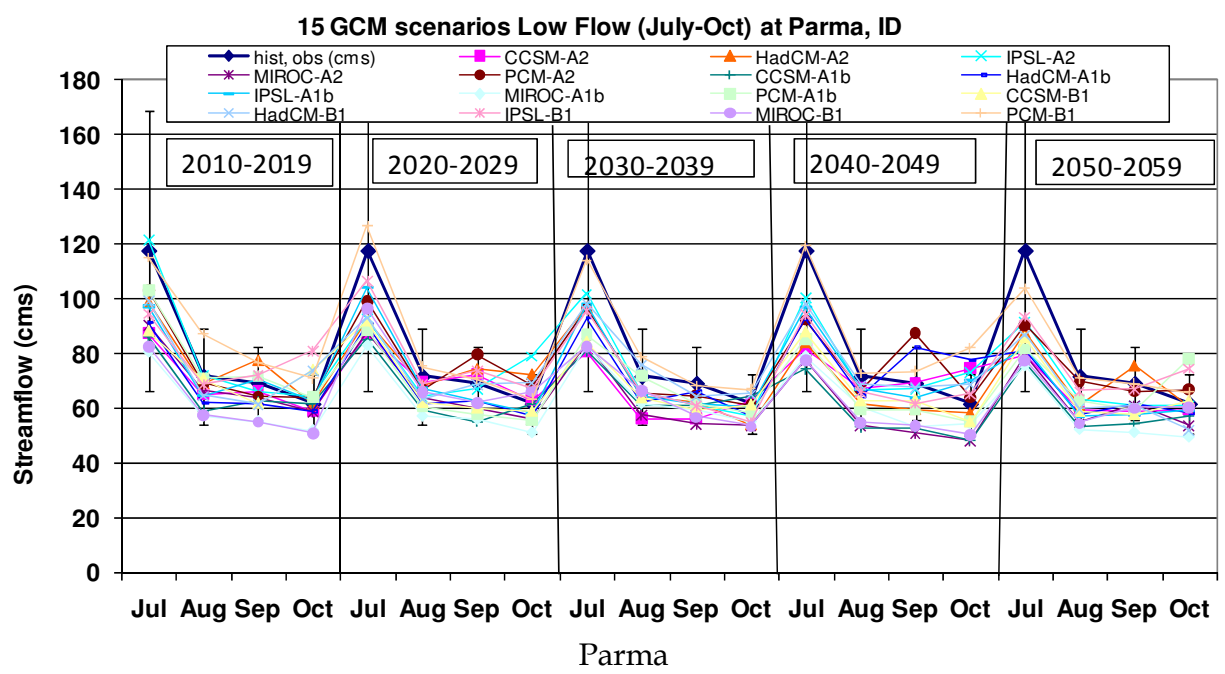

Fig. 10. Low flows for each decade between 2010 and 2060 at Twin Springs, Caldwell and Parma in the Boise River Basin.

\begin{tabular}{|c|c|c|c|}
\hline & A2 & A1B & B1 \\
\hline $\begin{array}{c}\text { Peak flow maximum } \\
\text { decrease (cms) }\end{array}$ & 17.6 & 18.7 & 17.2 \\
\hline $\begin{array}{c}\text { Peak flow maximum } \\
\text { increase (cms) }\end{array}$ & 5.5 & 2.2 & 9.5 \\
\hline $\begin{array}{c}\text { Peak flow mean decrease } \\
(\mathrm{cms})\end{array}$ & 8.0 & 10.7 & 6.2 \\
\hline
\end{tabular}

(a)

\begin{tabular}{|c|c|c|c|}
\hline & A2 & A1B & B1 \\
\hline $\begin{array}{c}\text { Peak flow maximum } \\
\text { decrease (cms) }\end{array}$ & 29.4 & 25.6 & 29.7 \\
\hline $\begin{array}{c}\text { Peak flow maximum } \\
\text { increase (cms) }\end{array}$ & 52.3 & 27 & 46.3 \\
\hline $\begin{array}{c}\text { Peak flow mean decrease } \\
(\mathrm{cms})\end{array}$ & -0.028 & -2.2 & 5.4 \\
\hline
\end{tabular}

(b)

Table 6. (a) The Boise River Basin future low flow change range (8-site average) between 2010-2060 for each scenario (A2, A1B and B1); (b) The Rathdrum Prairie Basin low future low change range (2-site average) between 2010-2060 for each scenario (A2, A1B and B1).

The volume of flow changes in the Boise River basin at Lucky Peak was also computed. This was done by computing the area under the hydrograph (by adding the ordinates through the trapezoidal method) with the historic volumes. Table 7 shows the decadal averages of increase in flow volumes in acre-ft for $\mathrm{A} 2, \mathrm{~A} 1 \mathrm{~B}$ and $\mathrm{B} 1$ scenarios. The increase in flow 
volumes are 249 ac-ft (A2), 149 ac-ft (A1B) and 327 ac-ft (B1). The overall average when combining all of these flow volumes results in increasing flow volume by $242 \mathrm{ac}-\mathrm{ft}$.(convert ac-ft to square kilometer-meter).

\begin{tabular}{|c|c|c|c|}
\hline & A2 & A1B & B1 \\
\hline $2010-2019$ & 248 & 120 & 228 \\
\hline $2020-2029$ & 89 & 97 & 472 \\
\hline $2030-2039$ & 236 & 125 & 215 \\
\hline $2040-2049$ & 340 & 270 & 442 \\
\hline $2050-2059$ & 332 & 132 & 279 \\
\hline Average & 249 & 149 & 327 \\
\hline
\end{tabular}

Table 7. Decadal changes in flow volumes (square kilometer-meter) between 2010-2060 for each scenario (A2, A1B and B1).

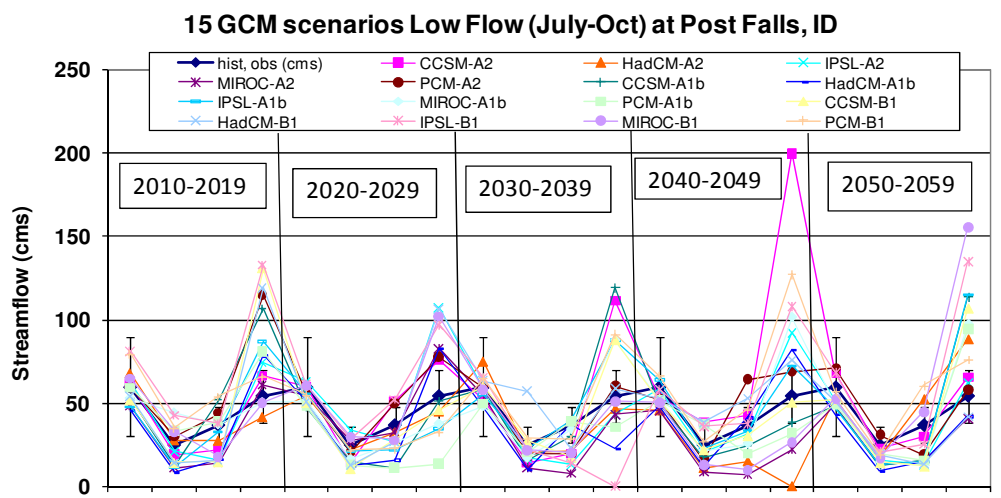

Jul Aug Sep Oct Jul Aug Sep Oct Jul Aug Sep Oct Jul Aug Sep Oct Jul Aug Sep Oct

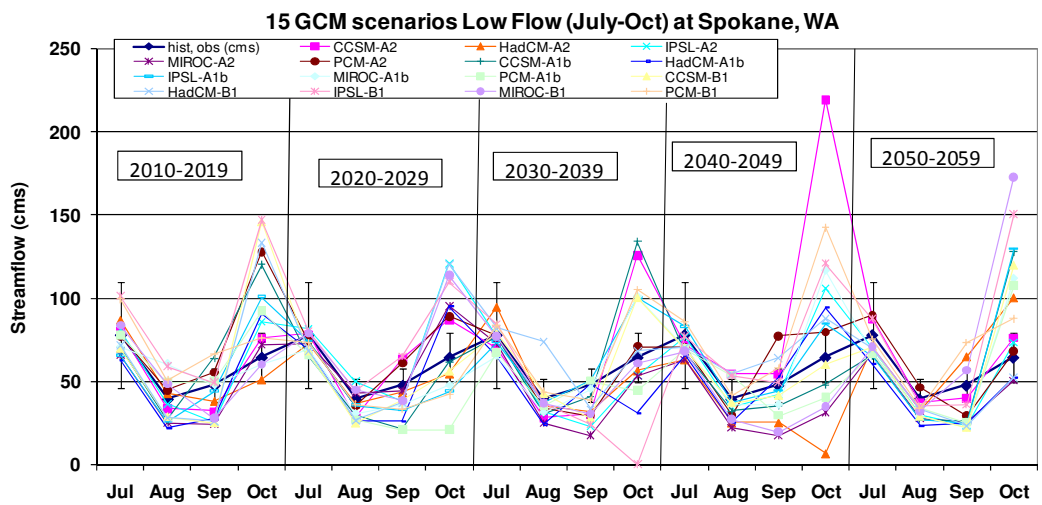

Fig. 11. Low flows for each decade between 2010 and 2060 at Post Falls in the Spokane River Basin. 


\subsection{Time maps}

When simulating the flows under the climate change scenarios, one of the main things is to verify the timing of peak flow and its shift in the future. Using the time maps, we show that there is a shift in timing for all the three emission scenarios at least by 3-4 weeks in the Rathdrum Prairie aquifer region whereas Boise River basin showed 2-3 weeks of shift in the timing of peak flow. This shift is significant when the runoff needs to be stored or released from the system for flood control or irrigation. If we have to let the inflows released due to earlier melting, potentially there will be less water available for the crop growing season water demand. If we consider storing them, an additional analysis is critical to see if we have adequate storage capacity and room for flood control in both the basins. Figure 12 shows Lucky Peak in the Boise River basin and Post Falls in the Rathdrum Prairie region for A2 scenario streamflow generation in the future. Recall that A2 scenario considers increased emission leading to higher temperatures than any other scenarios and therefore melt timing analysis it is appropriate to consider A2 as a worst case scenario where maximum shift to be expected.

\section{Simulated SWAT monthly flow for various climate model (A2) in Boise River Basin}

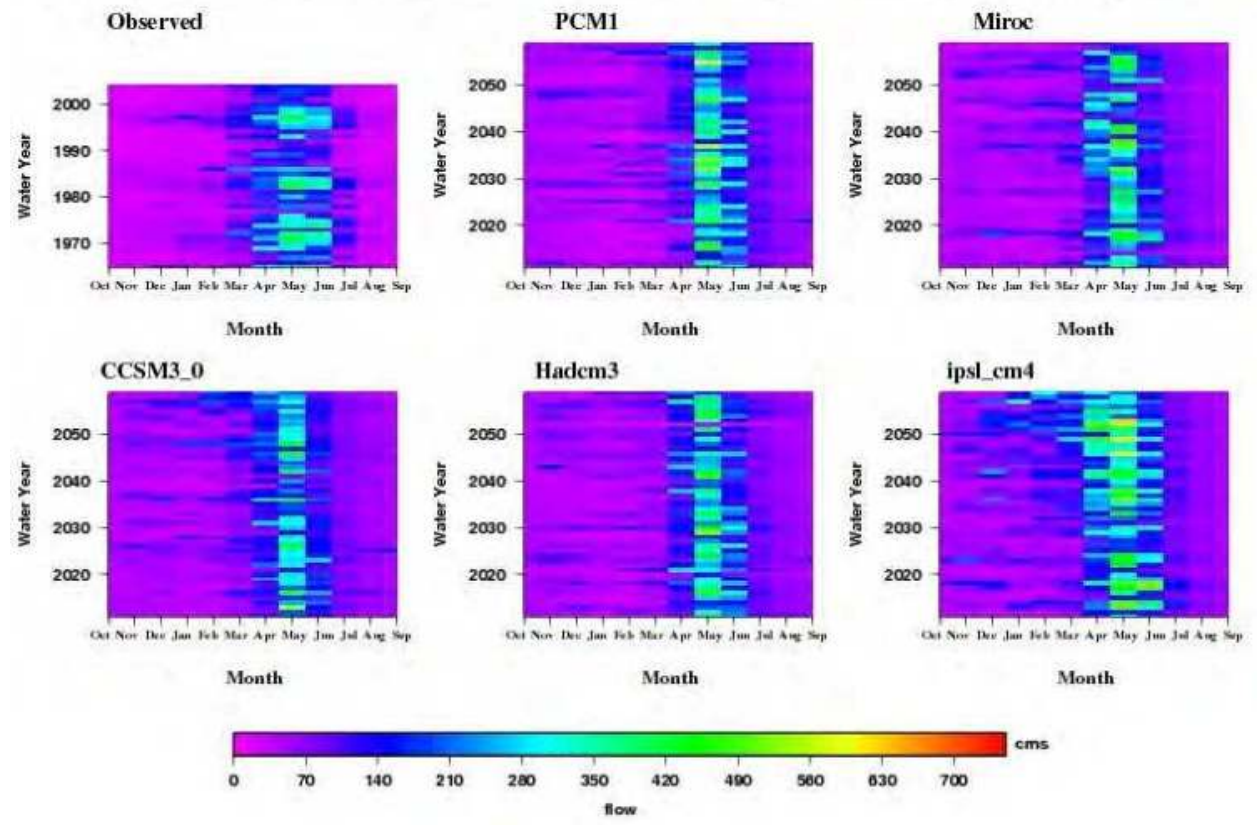

a. Lucky Peak, ID 


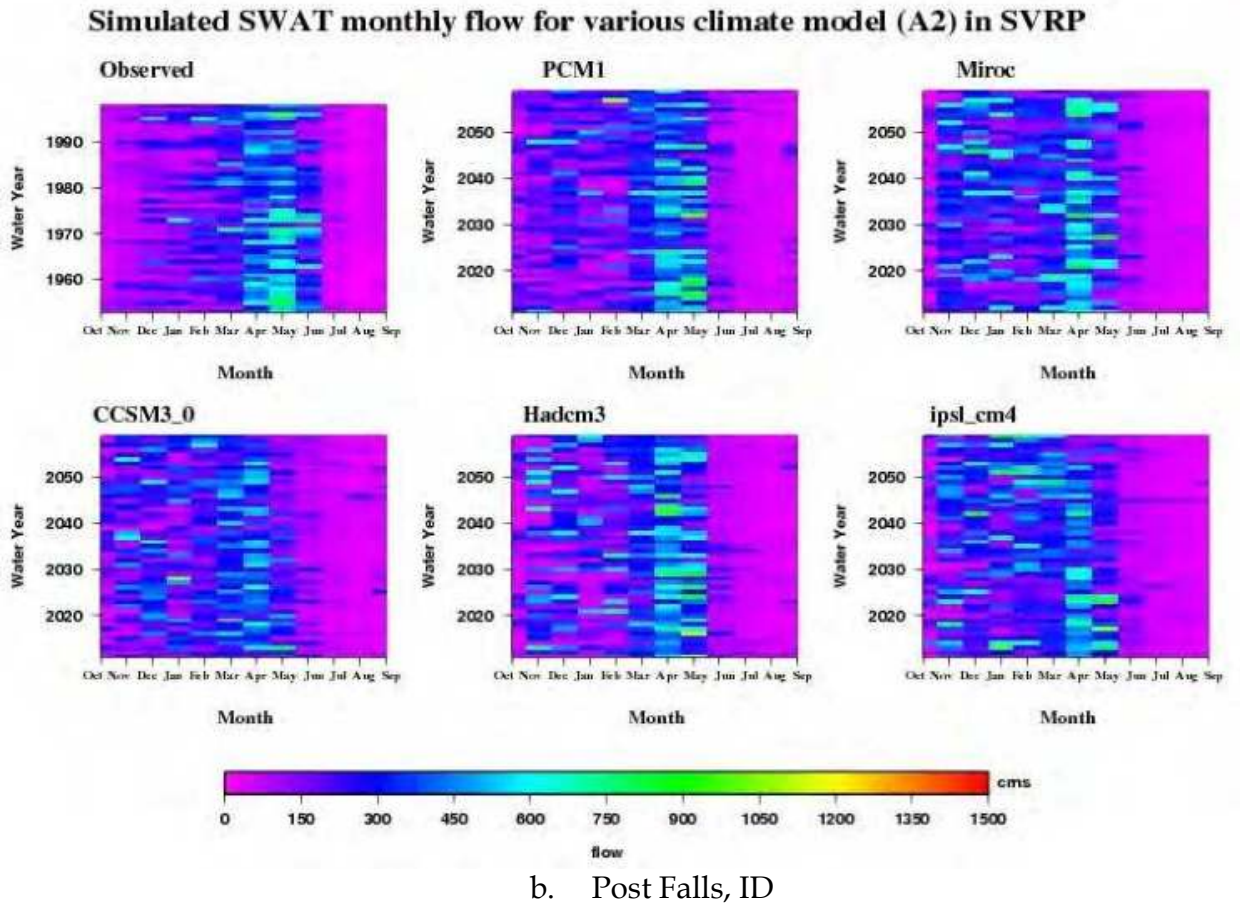

Fig. 12. Time maps at (a) Lucky Peak, ID in Boise River Basin and (b) Post Falls, ID in the Spokane River Basin.

\section{Conclusion}

In conclusion, we expect that on a regional basis an increase of $5-7^{\circ} \mathrm{F}$ in temperature as well as an increase in precipitation over the northwestern and north-central portions. Many global climate models also agree with a decrease in the April $1^{\text {st }}$ snowpack resulting in a decrease in streamflow of about 8 to $20 \%$. In general, the major river basins in PNW region such as the Columbia and Snake Rivers are expected to see an increase in December-March runoff and a decrease/increase in April-July (peakflow) and a decrease in July-October (low flow). While precipitation increases can result in increased runoff, a consistent pattern in temperature increase among all climate models can result in net decrease in annual runoff due to enhanced evapotranspiration under warming conditions. The PNW region is also expected to see more cool-season rainfall and runoff. In addition to precipitation and temperature changes, warming could lead to more intense and heavy rainfall interspersed with longer, relatively dry periods.

In this study, we identified five climate models that are relevant to capturing the future trends in precipitation and temperature. The models include CCSM3 (warmer and dry summer through 2020), HADCM3 (warmer and dry summer through 2040), IPSL CM4 (wetter winter), MIROC 3.2 (warmer and wetter winter) and PCM (cooler and dry summer). They represented a wide range of conditions and also change by time. After identifying the models, we downloaded the spatially downscaled climate model data from CMIP3 source 
developed by Bureau of Reclamation and other collaborators and subsequently temporally disaggregated them from monthly to daily to run the hydrology model. The precipitation forecast is less certain. In other words, some models predicted increased precipitation between 2010 and 2060 while other models predicted a decrease in precipitation. However, temperature increase is found to be consistent. For the Treasure Valley region, changes in precipitation ranged between $-3.8 \%$ and $36 \%$. Changes in temperature are expected to be between 0.02 and $3.9^{\circ} \mathrm{C}$. In the Rathdrum Prairie region, changes in precipitation are expected to be between $-6.7 \%$ and $17.9 \%$. Changes in temperature will likely be ranging between 0.1 and $3.5^{\circ} \mathrm{C}$. Overall, the chosen climate models showed a rise in temperature $\left(0.31{ }^{\circ} \mathrm{C}\right.$ to $0.42{ }^{\circ} \mathrm{C} /$ decade for Rathdrum Prairie and $0.34{ }^{\circ} \mathrm{C}$ to $0.46{ }^{\circ} \mathrm{C} /$ decade) and an increase in annual precipitation $(4.7 \%$ to $5.8 \%$ for Rathdrum Prairie and $5.3 \%$ to $8.5 \%$ for Treasure Valley) over a period of next five decades between 2010-2060

In order to study the response of the hydrology model due to changes in precipitation, we implemented the SWAT hydrology model to simulate the basin scale hydrologic response to changing climate. However, it is critical to calibrate the model based on the observed flow for multiple sub-basins in each basin. Therefore, we first calibrated the SWAT model for the Spokane River basin using the flows from Post Falls and Spokane. Similarly, we calibrated the model for the Boise River basin using the flows from Parma, Lucky Peak, Arrowrock, Twin Springs and Anderson Ranch. This calibration exercise resulted in 16 parameters adjusted for various processes within the basin including snowmelt, vegetation, groundwater and surface runoff. In both basins the model performance was evaluated using the $R^{2}$ values and we obtained a value of 0.6 or higher and that is considered to be good in the modeling environment for extending the simulation framework with selected parameters to another period.

The SWAT hydrology model was implemented under future climate conditions using the newly calibrated parameters. Considering a wide range of precipitation and temperature outlook, we expected predictions about the basin hydrology to express a broad range in streamflows, evapotranspiration and recharge during the simulation period of the entire 50 year period between 2010 and 2060. This was observed for all emission scenarios, A1B, A2 and B1 and based on the average of eight sites (Twin Springs, Anderson Ranch, Arrowrock, Lucky Peak, Glenwood, Middleton, Caldwell and Parma) in the Boise River basin the peak flows (March through June) appear to increase by $116.6 \mathrm{cms}$ (A2), $93.0 \mathrm{cms}$ (A1B) and 110.9 cms (B1). Also, decreased peak flows of $34.6 \mathrm{cms}$ (A2), $47.9 \mathrm{cms}$ (A1B) and $38.7 \mathrm{cms}$ (B1) are expected. These are due to some scenarios where precipitation is predicted to be decreasing. In general, the peak flow averages expected to increase by $17.6 \mathrm{cms}(\mathrm{A} 2), 11.0 \mathrm{cms}$ (A1B) and $22.4 \mathrm{cms}$ (B1). We averaged the two site predictions (Post Falls and Spokane) in the Rathdrum Prairie basin to understand the peak flow trends. It was found that increases are expected to be about $71.5 \mathrm{cms}$ (A2), $17.3 \mathrm{cms}$ (A1B) and $53.8 \mathrm{cms}$ (B1) based on the two site average flows predicted by the model. However, the decreases in peakflows are also greater than that of the Boise River Basin. For instance, a decrease in peak flows by $206.8 \mathrm{cms}$ (A2), $215.0 \mathrm{cms}$ (A1B) and $170.7 \mathrm{cms}$ (B1) were simulated by some scenarios.

The low flows (July-Oct) predicted by the model have projected decreasing flows by 17.6 $\mathrm{cms}$ (A2), $18.7 \mathrm{cms}$ (A1B) and $17.2 \mathrm{cms}$ (B1) in the Boise River basin. In the Rathdrum Prairie, a minimal increase in the average low flows, rather than a decrease as in the Treasure Valley region, by $5.4 \mathrm{cms}$ (B2) is simulated by these models. Thus, the low flows are expected to lower than historic low flows and high flows are anticipated to be higher than historic high flows and earlier. The Boise River and the Spokane River are tributaries to the Snake and 
Columbia River and as a result of this increased peak flow, we might anticipate that the Columbia River will have increased high flows and potential for flooding in the next decades.

We also anticipate a shift in the timing of snowmelt and this shift is advancing from current peak melt period of May to April. This has been consistent for both the basins. This is pretty typical of many regions in the Western U.S, including Pacific Northwest, which is expected to cause some management problems related to the water resources in the region. An earlier melt, if not stored, might cause some shortages in the system thereby possibly impacting various sectors including irrigated agriculture, hydro power and domestic as well as municipal water supply.

\section{Acknowledgement}

This research is supported by the NSF Idaho EPSCoR Program and by the National Science Foundation under award number EPS-0814387. Partial support came from NOAA via the Northwest Climate Decision Support Consortium (pnwclimate.org) under award number NA10OAR4310218. The authors would like to express gratitude for financial and technical support provided by in part by the Idaho Department of Water Resources under contract number CON00837.

\section{References}

Abbaspour, K. (2008). SWAT-CUP2: SWAT calibration and uncertainty programs - A user manual, Department of Systems Analysis, Integrated Assessment and Modelling (SIAM), Eawag, Swiss Federal Institute of Aquatic Science and Technology, Duebendorf, Switzerland, 2008, 95pp.

Barber, M.E., Hossain, A., Covert, J.J. \& Gregory, J.G. (2009). Augmentation of Seasonal Low Stream Flows by Artificial Recharge in the Spokane Valley-Rathdrum Prairie Aquifer of Idaho and Washington, USA. Hydrogeology Journal 17:1459-1470.

Bureau of Reclamation (2011). Secure Water Act Section 9503( c ) Reclamation Climate Change and Water 2011, U.S. Department of the Interior, Policy and Administration, Bureau of Reclamation, Denver, Colorado, April 2011, 226p

Caprio, J.M., Quamme, H.A. \& Redmond, K.T. (2009). A statistical procedure to determine recent climate change of extreme meteorological data as applied at two locations in the northwestern North America. Climatic Change 92(1-2): 65-81.

Hamlet, A.F., \& Lettenmaier, D.P. (1999). Effects of climate change on hydrology and water resources in the Columbia River Basin. Journal of American Water Resources Association, 35(6):1597-1632.

Jin, X. \& Sridhar, V. (2010). "Impacts of climate change on hydrology and water resources in the Boise and Spokane River Basins." Journal of the American Water Resources Association, in review.

Kunkel, K.E., Easterling, D.R., Hubbard, K. \& Redmond, K. (2004). Temporal variations in frost-free season in the United States 1895-2000. Geophysical Research Letters, 31, L03201, doi:10.1029/2003GL018624.

Maurer, E. P., Brekke, L., Pruitt, T. \& Duffy, P.B. (2007). Fine-resolution climate projections enhance regional climate change impact studies. Eos Trans. AGU, 88(47), 504. 
Mote, P.W. (2003). Trends in temperature and precipitation in the Pacific Northwest during the twentieth century. Northwest Science 77(4):271-282.

Mote, P.W. (2006). Climate-driven variability and trends in mountain snowpack in western North America. Journal of Climate 19(23): 6209-6220.

Stewart, I.T., Cayan, D.R. \& Dettinger, M.D. (2005). Changes toward earlier streamflow timing across western North America. Journal of Climate 18(8): 1136-1155.

Sridhar, V., \& Nayak, A. (2010). Implications of climate-driven variability and trends for the hydrologic assessment of the Reynolds Creek Experimental Watershed, Idaho. Journal of Hydrology, 385, 183-202, doi:10.1016/j.jhydrol.2010.02.020.

Stratton, B.T., Sridhar, V., Gribb, M.M., McNamara, J.P. \& Narasimhan, B. (2009). Modeling the spatially varying water balance processes in a semi-arid mountainous watershed of Idaho. Journal of the American Water Resources Association, 45 (6) , 13901408, DOI: 10.1111/j.1752-1688.2009.00371.x. 


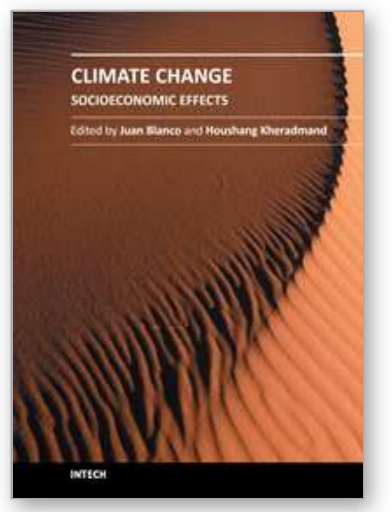

\author{
Climate Change - Socioeconomic Effects \\ Edited by Dr Houshan Kheradmand
}

ISBN 978-953-307-411-5

Hard cover, 454 pages

Publisher InTech

Published online 09, September, 2011

Published in print edition September, 2011

This book shows some of the socio-economic impacts of climate change according to different estimates of the current or estimated global warming. A series of scientific and experimental research projects explore the impacts of climate change and browse the techniques to evaluate the related impacts. These 23 chapters provide a good overview of the different changes impacts that already have been detected in several regions of the world. They are part of an introduction to the researches being done around the globe in connection with this topic. However, climate change is not just an academic issue important only to scientists and environmentalists; it also has direct implications on various ecosystems and technologies.

\title{
How to reference
}

In order to correctly reference this scholarly work, feel free to copy and paste the following:

Venkataramana Sridhar and Xin Jin (2011). Climate Change Impacts: An Assessment for Water Resources Planning and Management in the Pacific Northwest of the U.S, Climate Change - Socioeconomic Effects, Dr Houshan Kheradmand (Ed.), ISBN: 978-953-307-411-5, InTech, Available from:

http://www.intechopen.com/books/climate-change-socioeconomic-effects/climate-change-impacts-anassessment-for-water-resources-planning-and-management-in-the-pacific-nort

\section{INTECH}

open science | open minds

\section{InTech Europe}

University Campus STeP Ri

Slavka Krautzeka 83/A

51000 Rijeka, Croatia

Phone: +385 (51) 770447

Fax: +385 (51) 686166

www.intechopen.com

\section{InTech China}

Unit 405, Office Block, Hotel Equatorial Shanghai

No.65, Yan An Road (West), Shanghai, 200040, China 中国上海市延安西路65号上海国际贵都大饭店办公楼 405 单元

Phone: +86-21-62489820

Fax: $+86-21-62489821$ 
(C) 2011 The Author(s). Licensee IntechOpen. This chapter is distributed under the terms of the Creative Commons Attribution-NonCommercialShareAlike-3.0 License, which permits use, distribution and reproduction for non-commercial purposes, provided the original is properly cited and derivative works building on this content are distributed under the same license. 